\title{
EMPLOYEES' SUITS UNDER THE FAIR LABOR STANDARDS ACT
}

\author{
By Albert B. Gerber † and S. Harry Galfand
}

The Federal Fair Labor Standards Act ${ }^{1}$ has been in effect since October 24, I938. Nevertheless, during the federal fiscal year I946 more than half of the establishments subject to the Act were found to have been violating it. ${ }^{2}$. Since the Act provides for enforcement by private suit at the expense of the employer with recovery of additional amounts as liquidated damages, ${ }^{3}$ it was to be expected that a stream of cases would flow into the courts. The stream became a veritable flood in recent months when "portal to portal" suits ${ }^{4}$ became one of the main topics of news interest. While the substantive law that emerged from the earlier decisions has received a fair share of analysis, ${ }^{5}$ the procedural aspects of employees' suits under the Act, particularly in view of the "walking time" actions, merit closer study. It is the purpose of this article to consider primarily such procedural and allied aspects.

\section{INTRODUCTION}

Briefly stated, the Act provides that any employer who violates its minimum wage ${ }^{6}$ or overtime provisions ${ }^{7}$ shall be liable to the employees affected for (I) the total amount which was underpaid, (2) an additional equal amount as liquidated damages, (3) a reasonable attorney's fee, and (4) costs of the action. ${ }^{8}$ Assuming that a given case meets all the requirements of the Act for recovery, a host of preliminary questions will be met and must be resolved before final judgment is entered.

$\dagger$ Albert B. Gerber, B.S., I934, LL. B., I937, LL. M., 1940, University of Pennsylvania; M.A. Pub. Adm., I94I, The George Washington University; member of Philadelphia Bar.

$\ddagger$ S. Harry Galfand, B. S. Bus. Adm., I94I, St. Joseph's College; LL. B., I945, University of Pennsylvania; member of Philadelphia Bar.

I. 52 STAT. 1060 (1938), 29 U. S. C., \$20I (r940).

2. U. S. Dept. of Labor, Wage and Hour and Pub. Contracts Div. Release, Aug. 2, 1946. The exact percentage given by the Administrator was $52 \%$.

3. 52 STAT. 1069, 29 U. S. C., § 216 (1938).

4. See, e. g., Phila. Legal Intelligencer, Dec. 26 , 1946, p. I, col. I (I00 million dollar portal-to-portal suit against International Harvester); Phila. Legal Intelligencer, Dec. 24, I946, p. r, col. 4 (portal-to-portal suits total 534 million, claims still mounting).

5. See Dodd, The Supreme Court and Fair Labor Standards, I94I-I945 (I946) 59 Harv. L. REv. 322; Brundage, "Regular Rate" of Pay Under Section 7 (a) of the FLSA (1946) 34 CALIF. L. REv. 227; Ball, Piece Work Pay Under FLSA (1945) 6 AlA. LAw. 410; Simon, Contemporary Problems Under Federal Wage-Hour Law (1945) 50 CoMr. L. J. 75.

6. 52 STAT. I062 (I938), 29 U. S. C., \$ 206 (I940).

7. Id. at 1063,29 U. S. C., $\$ 207$ (1938).

8. Id. at 1069, 29 U. S. C., § 216 (I938). 


\section{Jurisdictional Problems}

\section{A. State or Federal Forum}

Where may the action be brought? In the State Court? In the Federal Court? In either? The Act itself seems to make the matter clear by stating that an employee's suit "may be maintained in any court of competent jurisdiction." 9 Notwithstanding this apparently clear legislative grant of jurisdiction, there was some early controversy on the subject. ${ }^{10}$ The controversy concerning jurisdiction is now solely a matter of historical and academic interest. Today, an employee's suit under the Act may be brought in any state ${ }^{11}$ or federal court ${ }^{12}$ having original jurisdiction over suits involving general contractual claims. State courts have jurisdiction over employees' suits because the Act specifically so provides. ${ }^{13}$ Federal courts have jurisdiction for the same reason and, moreover, because the Judicial Code gives jurisdiction to the federal courts over "all suits and proceedings arising under any law regulating interstate commerce." 14

\section{B. Removal}

If suit is started in a state court, there may be an attempt by the defendant to remove it to the federal court under the Federal Removal Act. ${ }^{15}$ This Act provides that "Any suit of a civil nature . . . arising under the Constitution or laws of the United States ... of which the district courts of the United States are given original jurisdiction . . . may be removed by the defendant . . . to the district court of the United States. . . ." Since the "district courts of the United States are given original jurisdiction" over FLSA suits by

9. 52 Stat. 1069, 29 U. S. C., § 216 (1938).

I0. Poole, Private Litigation Under the Wage and Hour Act (1942) I4 Mrss. L. J. I57, I58-9; Crockett, Jurisdiction of Employee Suits Under the Fair Labor Standards Act (I94I) 39 Micr. L. Rev. 4 I9.

II. Forsyth v. Central Foundry Co., 240 Ala. 277, I98 So. 706 (I940) ; Emerson v. Mary Lincoln Candies, Inc., I73 Misc. 53I, I7 N. Y. S. (2d) 851 (Sup. Ct. 1940); Hart v. Gregory, 218 N. C. I84, Io S. E. (2d) 644 (I940); Newman, Jr. v: Fuller Co., II C. C. H. Lab. Cas. I 63,274 (R. I., I946) ; Tapp v. Price-Bass Co., I77 Tenn. I89, I47 S. W. (2d) I07 (I94I); Stringer v. Griffin Grocery Co., I49 S. W. (2d) I58 (Tex. Civ. App. I94I).

I2. Shain v. Armour \& Co., 40 F. Supp. 488 (W. D. Ky. I94I) ; Lengel v. Newark Newsdealers Supply Co., 32 F. Supp. 567 (D. N. J. 1940) ; Campbell v. Superior Decalcomania Co., Inc., 3I F. Supp. 663 (N. D. Tex. I940).

13. Brockway v. Long, 55 F. Supp. 79 (W. D. Mo. I944); Brantley v. Augusta Ice \& Coal Co., 52 F. Supp. I58 (S. D. Ga. I943). See Sloan, Jurisdiction of State Courts in Actions Under Wage and Hour Law (I94I) J. B. AssN. KAN. 354

14. 36 STAT. I092 (I9II), 28 U. S. C., § 4I (8). Lengel v. Newark Newsdealers Supply Co., 32 F. Supp. 567 (D. N. J. 1940); Fishman v. Marcouse, 32 F. Supp. 460 (E. D. Pa. I940). See Reese, Concurrent Jurisdiction of State and Federal Courts Under Section 16 (b) of the FLSA (I94I) 27 VA. L. REv. 328.

15. 36 Stat. I094 (I9II), 28 U. S. C., § 7I (I940). 
virtue of Section 24 of the Judicial Code ${ }^{16}$ it would seem that such a suit is removable. Some courts have so held. ${ }^{17}$ This view, declared by one court to be a "reactionary interpretation," 18 has been rejected by the bulk of the courts that have considered the question; ${ }^{19}$ and one commentator has pointed out that "to confer removal jurisdiction on the federal court is to give it in practice exclusive jurisdiction at the option of the employer." 20

\section{Limitations Imposed by Federal Jurisdiction}

Most of the advantages and disadvantages inherent in either state or federal forum will become apparent as each of the succeeding points is developed. However, mention should be made of the fact that if the employees desire to sue in a federal court and to join their FLSA claims with an action on a contract, specific grounds for federal jurisdiction must be found. For example, in Timony $v$. Todd Shipyards Corp. ${ }^{21}$ the plaintiffs, in addition to their claim under the FLSA, sued for premium pay due under a collective bargaining contract. It was held that this claim required normal federal jurisdictional allegations ${ }^{22}$ in order to be sustained. ${ }^{23}$

\section{Parties}

\section{A. Plaintiff}

The Act specifies that any one or more employees may bring the action on behalf of himself or themselves and other employees similarly situated, or the employees may designate an agent or represen-

I6. 36 STAT. I094 (I9II), ì U. S. C., § 4I (8) (I940).

I7. Koskala v. Butler Bros., II C. C. H. Lab. Cas. \66,283 (D. Minn. I946); Cox v. Gatliff Coal Co., 52 F. Supp. 482 (E. D. Ky. 1943), order sustained I42 F. (2d) 876 (C. C. A. 6th, 1944). See Ricciardi v. Lazzara Baking Corp., 32 F. Supp. 956, 958 (D. N. J. I940). See also Ray and Young, The Removal of Employee Suits Brought Under the Fair Labor Standards Act (1945) 18 TENN. L. REv. 676; Notes (1942) 36 Ill. L. Rev. 787, (194I) 9 KaN. City L. Rev. 227.

18. Fredman v. Foley Brothers, 50 F. Supp. I6I, I62 (W. D. Mo. 1943); Cofer v. Hercules Powder Co., II C. C. H. Lab. Cas. I 63,276 (E. D. Tenn. 1946); Tobin v. Hercules Powder Co., 63 F。 Supp. 434 (D. Del. 1945) ; Steiner v. Pleasantville Constructors, Inc., 59 F. Supp. IOII (S. D. N. Y. I944).

19. Brockway v. Long, 55 F. Supp. 79 (W. D. Mo. I944); Brantley v. Augusta Ice \& Coal Co., 52 F. Supp. I 58 (S. D. Ga. I943); Garner v. Mengel Co., 50 F. Supp. 794 (W. D. Ky. 1943) ; Apple v. Shulman Publications, Inc., 7 C. C. H. Lab. Cas. II 6I,973 (D. N. J. I943).

20. Note (1942) 55 Harv. L. REv. 54I, 542.

2I. 59 F. Supp. 779 (S. D. N. Y. I945), aff'd, I5I F. (2d) 336 (C. C. A. 2d, 1945), cert. denied, 327 U. S. 779 (1946).

22. Kuhn v. Canteen Food Service, 9 C. C. H. Lab. Cas. I62,5I7 (N. D. Ill. 1944), I50 F. (2d) 55 (C. C. A. 7th, 1945). Accord: Schempf v. Armour \& Co., II C. C. H. Lab. Cas. 163,287 (D. Minn. I946). But see Crabb v. Welden Brothers, 65 F. Supp. 369 (S. D. Towa, 1946).

23. Contra: Adair v. Ferst, 45 F. Supp. 824 (N. D. Ga. 1942). 
tative to maintain the action. ${ }^{24}$ Thus, the employee may sue, ${ }^{25}$ or his assignee may bring the action, ${ }^{26}$ or he may designate an agent to present his claim. ${ }^{27}$ It seems obvious from the language of the Act that the employees' labor union may maintain the action. ${ }^{28}$ However, if a union brings the action the employees should not be individually named as plaintiffs. If this is done a motion to dismiss as to the union on the ground that it is a superfluous party plaintiff will be properly granted. ${ }^{2 \theta}$

\section{B. Group Actions}

Since a large number of employees can join, the suit has been likened to a "class action" under the Federal Rules. ${ }^{30}$ With respect to terminology the courts are in disagreement as to whether the suit is a "true class action," ${ }^{31}$ a "hybrid action" ${ }^{32}$ or a "spurious action." ${ }^{83}$ However, regardless of nomenclature and terminology the courts have reached certain definite conclusions with respect to these group actions, and, as Judge Goodrich has pointed out in connection with this problem, "there is divergence in the reasons assigned for the result." 34 At least the following rules have been established:

Any group of employees may band together and bring an action, notwithstanding the existence of differences among them "as to time worked, wages actually due and hours of overtime involved." ${ }^{35}$ There may even be "marked differences" ${ }^{36}$ in employment, but as long as

24. 52 Stat. 1069, 29 U. S. C., \$216 (b) (1940).

25. If the employee is a minor, suit should be brought by the minor's guardian. Constance v. Gosnell, 62 F. Supp. 253 (W. D. S. C. I945). In Baggett v. Henry Fischer Packing Co., 4 C. C. H. Lab. Cas. If 60,654 (W. D. Ky. I94I) a former employee brought the action.

26. Steiner v. Pleasantville Constructors, Inc., I8I Misc. 798,46 N. Y. S. (2d) I20

(N. Y. City Ct. I943), aff'd as modified, 182 Misc. 66, 49 N. Y. S. (2d) 42 (N. Y. Sup. Ct. 1944), aff'd, 269 App. Div. 738, 54 N. Y. S. (2d) 700 (Ist Dept. I945) ; Grippentrog v. Cheese Makers' Mfg. Co., 245 Wis. 1, 13 N. W. (2d) 391 (1944).

27. Hargrave v. Mid-Continent Petroleum Corp., $36 \mathrm{~F}$. Supp. 233 (E. D. Okla. I94I) ; Greenberg v. Bailey Lumber Co., 4 C. C. H. Lab. Cas. II 60,366 (Minn. Dist. Ct. St. Louis Co. 194I).

28. Building Serv. Employees Internat. Union, Local 238 v. Trenton Trust Co., 142 F. (2d) 257 (C. C. A. 3d, I944).

29. Cabunac v. National Terminals Corp., I39 F. (2d) 853 (C. C. A. 7th, 1944). See also Townsend v. Palmer, 35 F. Supp. 938, 940 (D. Mass. I940). 30. See Rohl, Class Action Device and Employee Suits Under the Fair Labor Standards Act (1942) 37 ILz. L. REv. II9. 2236.

31. See Note (1946) 46 Col. L. Rev. 818; 2 Moore, Federal Practice (1938)

32. See Pentland v. Dravo Corp., 4 F. R. D. 350 (W. D. Pa. 1945), rev'd, 152 F. (2d) 85 I (C. C. A. 3d, I945).

33. Ibid. See Saxton v. Askew Co., 35 F. Supp. 519, at 52I (N. D. Ga. 1940).

34. Pentland v. Dravo Corp., I52 F. (2d) 85I, 856 (C. C. A. 3d, 1945).

35. Saxton v. Askew, 35 F. Supp. 5 Ig (N. D. Ga. I940). See Jumps v. Leverone, I50 F. (2d) 876 (C: C. A. 7 th, 1945).

36. Distelhorst v. Day \& Zimmerman, 58 F. Supp. 334 (S. D. Iowa, 1944), appeal dismissed per curiam, 150 F. (2d) 54I (C. C. A. 8th, 1945). But cf. Rockwood v. Crown Laundry Co., 352 Mo. 56r, I78 S. W. (2d) 440 (I944) (where state procedural rules were held to prohibit joinder of dissimilar causes of action). Accord: Archer v. Musick, II C. C. H. Lab. Cas. $\Uparrow 63,234$ (Neb. I946). 
there is a peg upon which to hang the statutory language "employees similarly situated" the action may go forward. ${ }^{37}$ After the action has been begun other employees will be permitted to join through amendment of the complaint. ${ }^{38}$ However, the defendant will be protected by a motion to dismiss as against all unnamed employees who do not join within a reasonable length of time. ${ }^{38}$ Such a motion should not be made prematurely or it will be denied. ${ }^{40}$ Further protection is afforded the defendant in that employees who wait until after the Statute of Limitations has run will not be permitted to join. ${ }^{41}$ As to each newly joining employee the action will be deemed commenced as of the date of joinder. ${ }^{42}$

All employees who would recover must join. None who are not plaintiffs, intervenors, or named and authorizing litigants, may recover. ${ }^{43}$ One commentator has criticized this rule, arguing that its "practical effect . . . is to vitiate the class-suit provision of the FLSA." 44 However, this criticism is of questionable validity since any number of employees may indicate their assent to the suit and thus create a class-suit by group action and employees who do not join are not bound.45 A contrary rule would create a "startling result," 46 namely that employees who know nothing of the action might be bound by the judgment therein.

37. Dolan v. Day \& Zimmerman, Inc., 8 C. C. H. Lab. Cas. $\pi 62,189$ (D. Mass. I943) (office employees and shop employees permitted to be joined in one action); McNorrill v. Gibbs, 45 F. Supp. 363 (E. D. S. C. 1942).

38. Culver v. Bell \& Loffland, 146 F. (2d) 29 (C. C. A. 9th, 1944); Fineshewitz v. East River Savings Bank, 63 N. Y. S. (2d) 885 (N. Y. City Ct. 1946).

39. Wilson v. F. J. Egner \& Sons, Inc., 53 F. Supp. 847 (N. D. Ohio, 1944); Orton v. Basic Magnesium, Inc., Io C. C. H. Lab. Cas. Ø 62,887 (D. Nevada, 1945); Pentland v. Dravo Corp., 4 F. R. D. 350 (W. D. Pa. I945), rev'd, I52 F. (2d) $85 I$ (C. C. A. 3d, 1945).

40. Pentland v. Dravo Corp., I52 F. (2d) 85I (C. C. A. 3d, I945) ; Townsend v. Palmer, 35 F. Supp. 938 (D. Mass. r940). Where appeals consume a considerable period of time a new allowance for intervention will be made. Tennessee Coal, Iron \& R. R. Co. v. Muscoda, Local I23, 5 F. R. D. I74 (N. D. Ala. I946).

4I. Robertson v. Alaska Juneau Gold Min. Co., 6r F. Supp. 265 (N. D. Cal. I945), rev'd on other grounds, II C. C. H. Lab. Cas. Tf 63,424 (C. C. A. 9th, I946).

42. Barb v. Manhattan Laundries, Inc., II C. C. H. Lab. Cas. If63,210, II5 N. Y. L. J. 2207 (N. Y. City Ct. I946). Contra: Wright v. United States Rubber Co., II C. C. H. Lab. Cas. I 63,36I (S. D. Iowa, 1946).

43. Jumps v. Leverone, I50 F. (2d) 876 (C. C. A. 7th, I945); Timberlake v. Day \& Zimmerman, Inc., 49 F. Supp. 28 (S. D. Iowa, I943); Lewis v. Florida Power \& Light Co., 8 C. C. H. Lab. Cas. \62,306 (S. D. Fla. I943), rew'd on other grounds, ro C. C. H. Lab. Cas. $\llbracket 63,070$ (C. C. A. 5th, 1946).

44. (1942) 55 HARV. L. REv. 688.

45. See Pentland v.-Dravo Corp., I52 F. (2d) 85 r, 853 (C. C. A. 3d, I945).

46. Ibid. 


\section{Authority to Bring Action}

The plaintiff, when suing on behalf of other employees, should have specific authority to bring the action. ${ }^{47}$ Failure to disclose the authority is not necessarily fatal and does not render the complaint subject to a motion to dismiss, but the defendant may move to compel the plaintiff to disclose his right to bring the action. ${ }^{48}$ The names of all employees whose written authorizations the plaintiff fails to produce will be eliminated. ${ }^{49}$

\section{Survival of the Action}

In the event of the death of an employee prior to institution of the suit, it would seem that the action survives and an administrator or executor may sue. ${ }^{50}$ In several cases this procedure was successfully employed. ${ }^{51}$ Where the employee-plaintiff died after suit was begun the substitution of the deceased's administrator was permitted, ${ }^{52}$ and where an employee was adjudicated a bankrupt the court indicated that his claim passed to the trustees and the employee could not later enforce it. ${ }^{53}$

\section{E. Defendant}

A successful action under the FLSA requires that the defendant shall be the "employer." 54 If an employer's successor or assignee is made defendant an additional factor is present, and although the action may be maintained, it is no longer solely a suit under the FLSA. ${ }^{55}$ However, a mere bookkeeping transfer of the business to create a new employer will not relieve the apparent employer of liability under the Act. $^{58}$

47. Jumps v. Leverone, I50 F. (2d) 876 (C. C. A. $7^{\text {th }}$, 1945); Thomas v. Keystone Silver, Inc., I74 Misc. 733, 22 N. Y. S. (2d.) 796 (N. Y. Sup. Ct. 1940).

48. Shannon v. Franklin Simon \& Co., I8I Misc. 939,43 N. Y. S. (2d) 442 (N. Y. Sup. Ct. 1943).

49. Paranteau v. Swift \& Co., II C. C. H. Lab. Cas. I63,289 (D. Minn. I946).

50. See Poole, supra note Io, at I62.

5I. Porter v. Georgia Power \& Light Co., 50 F. Supp. 959 (M. D. Ga. I943); Southern Package Corp. v. Walton, Admx., Ig6 Miss. 786, 18 So. (2d) 458 (1944), cert. denied, 323 U. S. 762 (1944); De Luca v. West 26 th St. Corp., II C. C. H. Lab. Cas. $\Uparrow 63,255$ (N. Y. City Ct. I946).

52. Fletcher v. Grinnell Bros., ix C. C. H. Lab. Cas. \63,168 (E. D. Mich. 1946).

53. Burns v. Gilpin, I82 Tenn. 535, I88 S. W. (2d) 338 (1945).

54. Bowman v. Pace Co., IIg F. (2d) 858 (C. C. A. 5th, I94I); see Fanning v. Machinery Builders, Inc., to C. C. H. Lab. Cas. II 62,987, II4 N. Y. L. J. I745 (N. Y. City Ct. I945). A managing agent of a building may be the employer and liable as such. Asselta v. I 49 Madison Ave. Corp., Io C. C.:H. Lab. Cas. 162,907 (S. D. N Y. 1946), aff'd, i I C. C. H. Lab. Cas. 介 63,212 (C. C. A. 2d, I946) For the problem of employees as associates of a partnership see (I942) 56 HARv. $\dot{L}$. REv. 478 and Shea v. Wadsworth, II C. C. H. Lab. Cas. $\pi 63,326$ (E. D. N. Y. I946).

55. Davis v. Onyx Oils \& Resins, Inc., 63 F. Supp. 777 (D. N. J. 1946); Townsend v. Palmer, 35 F. Supp. 938 (D. Mass. 1940).

56. Ridgeway v. Warren, 6o F. Supp. 363 (M. D. Tenn. I945). 
Suits against dissolved corporations should be brought promptly or they will be barred. In two cases where a corporate employer was dissolved pursuant to statute and under court supervision, employees' FLSA claims, not filed during dissolution, were rejected by the court. ${ }^{57}$ A similar rule has been applied to bar a claim, not filed promptly as required by a state probate statute, against a deceased employer. ${ }^{58}$

Where there is a question of which of two defendants is the "employer" it would seem proper to join both. ${ }^{50}$

\section{The Complaint}

\section{A. Jurisdictional Allegations}

Obviously, the normal allegations of the existence of employment, violation of the Act, etc., must be set forth in the complaint. From the reported cases it appears that there has been no failure to set forth these elementary averments. However, one jurisdictional allegation has caused difficulty-the statement relating to interstate commerce.

Under the Act an employer is liable only if the employee "is engaged in commerce or in the production of goods for commerce." 60 The complaint must thus set forth facts which, if proved, would demonstrate that the employee is engaged in interstate commerce or in the production of goods therefor. Failure to allege such facts renders the complaint vulnerable to a motion to dismiss. ${ }^{01}$ It is insufficient to allege that the employer is engaged in interstate commerce. ${ }^{\mathbf{2}}$ Finally, the allegations should not be couched in conclusions but in intermediate facts from which an appropriate conclusion can be drawn. ${ }^{63}$

57. Wolf v. Miesch Realty Corp., 9 C. C. H. Lab. Cas. $\pi 62,58$ I (S. D. N. Y. 1945); Rieck v. Iowa Guarantee, Inc., 7 C. C. H. Lab. Cas. 161,564, I 61,624 (S. D. Iowa, 1943).

58. Hays v. Bank of America National Trust \& Savings Ass'n., 7I Cal. App. (2d) 30r, I62 P. (2d) 679 (1945), cert. denied, 66 Sup. Ct. 979 (1946). See also In re New Style Hat Mfg. Co., 43 F. Supp. I22 (N. D. Ohio, I940) where the employee waited a considerable length of time before filing a claim against an employer in bankruptcy. The claim was disallowed on a basis of proof but the delay in pressing the claim was emphasized. However, in Plourde v. Massachusetts Cities Realty Co., 47 F. Supp. 668 (D. Mass. 1942) it was held that a final decree entered in a reorganization under the Bankruptcy Act discharging the debtor of all debts was inoperative to bar a claim under the FLSA.

59. Mid-Continent Pipe Line Co. v. Hargrave, I29 F. (2d) 655 (C. C. A. Ioth, I942) (joint judgment against both defendant companies authorized); Ferrara v. Pratt-Smith Produce Corp., 8 C. C. H. Lab. Cas. II 62,204 (S. D. N. Y. 1944).

60. 52 STAт. 1062-3 (1938), 29 U. S. C., \$\$206, 207 (1940).

6I. Foster v. National Biscuit Co., 3I F. Supp. 552 (W. D. Wash. I940) ; Watt v. McWilliams Dredging Co., 9 C. C. H. Lab. Cas. $\pi 62,392$, II2 N. Y. L. J. II30 (N. Y. City Ct. 1944) ; Oliphant v. Kaser, to C. C. H. Lab. Cas. I 62,928 (Iowa, 1945).

62. McCarthy y. American Surety Co., I83 Misc. 983,52 N. Y. S. (2d) 601 (Sup. Ct. 1944), appeal dismissed, 270 App. Div. 751, 6r N. Y. S. (2d) 369 (Ist Dept. 1946). Accord: Baggett v. Henry Fischer Packing Co., 37 F. Supp. 670 (W. D. Ky. I94I). 63. Broderick v. Lemkau-Kidd Corp., 267 App. Div. 9I, 44 N. Y. S. (2d) 505 (Ist Dept. I942). Accord: Gustafson v. Fred Wolferman, Inc., ro C. C. H. Lab. Cas. $\pi 62,774$ (W. D. Mo. I945); Feinman v. Fleischer, 48 N. Y. S. (2d) 865 (Sup. Ct. 


\section{B. Specificity of Facts Relating to Overtime and Pay}

It is obvious that employees suing under the FLSA are not armed with facts and figures enabling them to allege in detail the number of overtime hours worked, the dates on which the work was performed, and other details normally required of the pleader. However, since the Act requires the employer to keep such records, ${ }^{64}$ the courts have been lenient and have not stricken down complaints for failure to specify the details of employment, ${ }^{65}$ and have refused to grant defendants' motions for bills of particulars to obtain greater details concerning the employees' claims. ${ }^{6 B}$

One court aptly explains this rule as follows:

"The alleged failure of the plaintiffs to state a claim upon which relief can be granted is in effect a criticism of the plaintiffs' inability to set out the exact hours and the exact amounts that will be in controversy. Such a failure cannot be deemed fatal when consideration is given to the probability that the plaintiffs are without definite and exact knowledge of the hours and wages in controversy, whereas the defendants, undoubtedly, have full and complete records bearing on this matter." 67

In this connection the model complaint prepared by the General Counsel of the United Steel Workers of America, CIO, contains the following paragraph:

"Plaintiffs are not informed as to the exact amount of overtime rendered by each of the employees or the wages still due and owing for overtime hours worked for which no payment was made, in violation of the Fair Labor Standards Act. Such information is not available to the employees who are represented in this action. But the records are, or should be, under the provisions of the said Act, in the exclusive possession of the defendant herein." 68

I944) ; Emanuele v. Rochester Packing Co., Inc., I82 Misc. 348,45 N. Y. S. (2d) 164 (Sup. Ct. I943) ; cf. Doyle v. Johnson Bros., Inc., 25 N. Y. S. (2d) 603 (N. Y. City Ct. I94I).

64. 52 StAT. 1066 (I938), 29.U. S. C., §2II (c) (I940).

65. Ballard v. Consolidated Steel Corp., 6r F. Supp. 996 (S. D. Cal. 1945); Townsend \& Yancey v. Boston \& Maine R., R., 3 C. C. H. Lab. Cas. I 60,200 (D). Mass. I940). Accord: Stangler v. Calvert Mfg. Co., II5 N. Y. L. J. 2IIg (N. Y. Sup. C.. 1946).

66. Dykema v. Aluminum Co. of America, II C. C. H. Lab. Cas. If63,r44 (N. D. I11. 1946); Snyder v. Gurnsey, 43 F. Supp. 204 (D. N. H. I942) ; Mitchell v. Brown, 6 C. C. H. Lab. Cas. I 61,140 (D. Neb. I942) ; Potts v. Stedman Co., 5 C. C. H. Lab. Cas. If 6r,021 (Ohio, 1942).

67. Townsend v. Palmer, 35 F. Supp. 938, 940 (D. Mass. I940).

68. United Steelworkers of America, Instructions in Procedure in Travel Time Cases, Nov. I, 1946, p. 14. 
However, where the facts relating to employment are known to the plaintiff such facts should be pleaded in full or the complaint will be found defective. ${ }^{69}$

\section{Exemptions}

Although the Act contains a series of exemptions, ${ }^{70}$ the courts have held that there is no need for the complaint to allege facts negating the existence of an exemption. ${ }^{71}$ If an employer intends to defend on the ground of the existence of an exemption it is an affirmative defense and must be set forth by him as such. ${ }^{72}$ This is in keeping with the general rule that no complaint will be dismissed unless the plaintiff could not recover under any set of facts which could be proved under the allegations in the complaint. ${ }^{73}$

\section{Preliminary Motions of the Defense}

\section{A. Bill of Particulars}

When first served with a complaint under the FLSA the defendant employer's first questions are likely to be: "who is suing, for how long, and for how much?" Therefore, the first motion of the defense attorney is frequently a bill of particulars or a motion for a more definite statement. Occasionally this is granted and the employees are required to set forth extensive and detailed information; ${ }^{74}$ or where the basis of the claim is unclear the employees will be compelled to clarify. ${ }^{75}$ More frequently, however, the courts either rule that since the information, in the form of payroll records and time cards, "is peculiarly within the knowledge of the defendant" 76 a bill of particulars

69. Renner v. Jackson \& Co., 10 C. C. H. Lab. Cas. II 62,808, II4 N. Y. L. J. I037 (Sup. Ct. I945).

70. 52 Stat. I067 (1938), 29 U. S. C., \$213 (1940).

71. Warner v. T. E. Collins Trucking Co., II C. C. H. Lab. Cas. 163,152 (W. D. La. I946); Wallach v. Merit Paper Corp., 58 N. Y. S. (2d) 531 (Sup. Ct. 1945); Thornberg v. E. T. \& W. N. C. Motor Transportation Co., I78 Tenn. 298, I57 S. W. (2d) 823 (1940). In Anderson v. Material Co-ordinating Agency, Inc., 63 N. Y. S. (2d) 324 (Sup. Ct. 1946), where plaintiff apparently pleaded absence of exemption, he was given burden of proving the allegation and could not carry it.

72. Schmidtke v. Conesa, I4I F. (2d) 634 (C. C. A. Ist, 1944) (in federal court exemption in a special defense under Fen. Rutes Civ. Proc.), Rule 8 (c).

73. Castaing v. Puerto Rican American Sugar Refinery, I45 F. (2d) 403 (C. C. A. Ist, 1944); Mennicucci v. F. \& P. Brakelyn Service, Inc., 58 F. Supp. 720 (D. N. J. 1945). 1945).

74. Orton v. Basic Magnesium, Inc, ro C. C. H. Lab. Cas. $\llbracket 62,887$ (D. Nev.

75. Warner v. T.E. Collins Trucking Co., II C. C. H. Lab. Cas. I6 63,152 (W. D. La. 1946).

76. Cuascut v. Standard Dredging Co., 9 C. C. H. Lab. Cas. 162,421 (D. Puerto Rico, r944). 
will be denied ${ }^{77}$ or the motion is limited so as to require the employee to set forth only such information as he obviously possesses, such as the approximate date he entered and left the employment of the defendant. ${ }^{78}$ This is a reasonable rule designed to ease the burden on the employer in his record-checking.

Objections to a bill of particulars must be made promptly or the employee is regarded as having waived the objections. ${ }^{79}$

\section{B. Arbitration}

In many cases the employees who make claim for additional compensation under the FLSA are subject to a collective bargaining agreement which provides for arbitration of disputes or controversies relating to terms and conditions of employment. The employer may desire to have the FLSA claim adjudicated by an arbitrator rather than by a jury.

In the federal courts this raises the question of the applicability of the United States Arbitration Act. ${ }^{80}$ From a reading of the Arbitration Act itself one would not believe that it was intended to apply to FLSA suits and would further conclude that a motion to stay court proceedings pending arbitration should not be granted on the basis thereof. The Arbitration Act specifically excludes from coverage "contracts of employment of . . . workers engaged in foreign or interstate commerce." 81 Notwithstanding this provision, and without discussing it, the Third Circuit Court of Appeals sustained the district court in granting a stay of proceedings pending arbitration. ${ }^{82}$ Subsequently the Fourth Circuit agreed ${ }^{83}$ and the Sixth Circuit disagreed. ${ }^{84}$ The question again arose in the Third Circuit and Judge Goodrich attempted to solve the dilemma and adhere to the earlier decision, by pointing out that Section 3 of the Arbitration Act, ${ }^{85}$ which provides for a stay pend-

77. Dykema v. Aluminum Co. of America, II C. C. H. Lab. Cas. I63,I44 (N. D. IIl. 1946); Dolan v. Day \& Zimmerman, Inc., 8 C. C. H. Lab. Cas. $\ 62,189$ (D. Mass. 1943); Keyer v. Hope Estates, Inc., 53 F. Supp. I004 (S. D. N. Y. 1943); Snyder v. Gurnsey, 43 F. Supp. 204 (D. N. H. 1942).

78. Ballard v. Consolidated Steel Corp., 6I F. Supp. 996 (S. D. Cal. 1945).

79. Eiring v. White Metal Rolling Stamping Corp., Io C. C. H. Lab. Cas. If 62,700, 113 N. Y. L. J. 2403 (N. Y. Sup. Ct. I945).

80. 43 Stat. 883 (1925), 9 U. S. C., \$§ I et seq. (I940). See Cohen and Dayton, The New Federal. Arbitration Law (I926) I2 VA. L. Rev. 265.

81. 43 Stat. 883 (1925), 9 U. S. C., § I (1940).

82. Donahue v. Susquehanna Collieries Co., I38 F. (2d) 3 (C. C. A. 3d, I943); (I944) I3 Ford. L. REv. IO9. 1944).

83. Agostini Bros. Bldg. Corp. v. United States, I42 F. (2d) 854 (C. C. A. $4^{\text {th, }}$

84. Gatliff Coal Co. v. Cox, I42 F. (2d) 876 (C. C. A. 6th, I944).

85. 43 STAт. 883 (1925), 9 U. S. C., \$3 (1940). 
ing arbitration, does not reiterate the earlier limitation of the Act's effectiveness to particular types of contracts. ${ }^{86}$

Other courts have considered the question, and applicability of the federal and state arbitration acts has been denied. ${ }^{87}$

In view of the conflict among the federal courts the eventual solution will probably require a decision by the Supreme Court. Certain considerations are pertinent. Arbitration, as normally practiced, with power in the hands of the arbitrator to render a decision and award irrespective of rules of law or normal findings of fact, ${ }^{88}$ cannot apply to suits under the FLSA without creating a severe departure from the present trend of decisions under the Act. For example, it is held that the employee's claim to overtime pay and liquidated damages is a public right and therefore cannot be settled, released, compromised, or otherwise terminated except by full compliance with the Act, ${ }^{89}$ and the Supreme Court has refused to allow union-employer collective bargaining agreements to deprive employees of their full rights under the Act. ${ }^{80}$ However, if the normal rules of arbitration are to be applicable to the arbitrator's decisions under the FLSA the result will be that although the courts are strictly bound by the provisions of the Act, and all parties except those working under an arbitration agreement are strictly bound, such employees and employers as come within an appropriate arbitration agreement are bound only insofar as the arbitrator sees fit to bind them.

While the Arbitration Act permits vacation or modification of an award solely on the grounds of fraud, corruption, collusion, bias, miscalculation of figures, and the like, ${ }^{01}$ it is questionable whether the Supreme Court will sustain an arbitrator's award contrary to the principles of law the Court has developed concerning the Act.

In view of the discrepancy between the normal processes of arbitration and the rigid rules governing FLSA claims, if the rule authorizing stays pending arbitration is to be sustained some judicial control

86. Watkins v. Hudson Coal Co., I5I F. (2d) 3II (C. C. A. 3d, 1945) at 320, cert. detied, 66 Sup. Ct. 522 (I946).

87. Ballard v. Consolidated Steel Corp., Itd., 6r F. Supp. 996 (S. D. Cal. I945); Bailey v. Karolyna Co., 50 F. Supp. I42 (S. D. N. Y. I943); see Adams v. Union Dime Savings Bank, 48 F. Supp. 1022 (S. D. N. Y. I943); Garrity v. Bagold Corp., 180 Misc. 120, 42 N. Y. S. (2d) 257 (Sup. Ct. 1943) ; McClintock v. Garment Center Capitol, Inc., 7 C. C. H. Lab. Cas. IT 6r,814, rIo N. Y. L. J. ro22 (Sup. Ct. I943) (considered opinion rejecting doctrine of Third Circuit Court of Appeals and accepting Bailey v. Karolyna Co., supra).

88. See James Richardson \& Sons, Itd. v. W. E. Hedger Transp. Co., 98 F. (2d) 55 (C. C. A. 2d, 1938) at p. 57: "The arbitrators, for reasons deemed sufficient to them, made the awards as indicated. This court is without power to amend or overrule merely because of disagreement with matters of law or facts determined by the arbitrators."

89. See infra Section VII B.

90. Martino v. Michigan Window Cleaning Co., 327 U. S. 173 (1946).

9I. 43 StAr. 885 (I925), 9 U. S. C., §§ II, I2 (I940). 
over the arbitrator will be necessary. Perhaps a clue to this is found in the dictum of Judge Goodrich in the Watkins case ${ }^{92}$ to the effect that the question of time worked under the FLSA "is the kind of problem which is properly referable to a special master or an arbitrator." The linking of an arbitrator to a master is significant since a master's findings are findings only "to the extent that the court adopts them," ${ }^{83}$ and the' master's conclusions of law are thoroughly reviewable by the court. ${ }^{94}$ The reconciliation of the rules concerning arbitrators and those with respect to masters may cause some difficulty. However, the judicial process has not been balked by more difficult dilemmas, and we shall very likely soon see a special rule relating to arbitrators of FLSA claims.

\section{Discovery}

\section{A. Pre-trial}

In the federal courts the normal methods of pre-trial discovery are available to the plaintiff. The use of interrogatories under Federal Rule 33 has been a common procedure. ${ }^{95}$ Another method utilized has been the motion, under Rule 34 , to permit the plaintiff to inspect the employer's books and payrolls. ${ }^{96}$ If this involves extensive research the court may appoint a master to conduct the discovery. ${ }^{97}$ Occasionally a request for the admission of facts under Rule $36^{98}$ or a pretrial examination under the Rules has been used. ${ }^{99}$

In a recent case the unusual method of discovery (from the plaintiff's viewpoint) of a bill of particulars was used. Since the defendant filed an answer dealing with the facts relating to the plaintiff's employment, the employee-plaintiff was held entitled to demand a complete answer setting forth in full all relevant details of employment. ${ }^{100}$

92. Watkins v. Hudson Coal Co., I5I F. (2d) 3II, 313 (C. C. A. 3d, 1945), cert. denied, 327 U. S. 777 (1946).

93. FED. Rules Crv. PROC., Rule 52 (e). The trial court must accept the master's findings of fact unless clearly erroneous. In re Chicago \& N. W. Ry. Co., I38 F. (2d) 753 (C. C. A. 7th, 1943), cert. denied, 32I U. S. 789 (1944).

94. Socony-Vacuum Oil Co. v. Oil City Refiners, Inc, 136 F. (2d) 470 (C. C. A. 6th, 1943), cert. denied, 320 U. S. 798 (I943) ; Arrow Distilleries, Inc. v. Arrow Distilleries, Inc., I28 F. (2d) $84 \mathrm{I}$ (C. C. A. 7 th, 1942); see 8 Cyclopedia of FederAL PROCEDURE (I943) $\$ 3452$.

95. Used in Mason v. Refiners Transport \& Terminal Corp., II C. C. H. Lab. Cas. II 63,I06 (N. D. Ohio 1946); Jumps v. Leverone, II C. C. H. Lab. Cas. If 63,172 (N. D. III. I946); Shain v. Armour \& Co., 40 F. Supp. 488 (W. D. Ky. I94I). I946).

96. Swoboda v. Carton Finishers, Inc., II C. C. H. Lab. Cas. f $63,4 I 7$ (N. D. Ill.

97. Fishman v. Marcouse, 32 F. Supp. 460 (E. D. Pa. 1940). 1945).

98. Strasser v. Fascination Candy Co., Io C. C. H. Lab. Cas. $\{62,891$ (N. D. I11.

99. Teichman v. Williamsburgh Fireproof Products Corp., 8 C. C. H. Lab. Cas. II 62,04I (E. D. N. Y. I944). I946).

roo. Winslow v. National Electric Products Corp., 5 F. R. D. I26 (W. D. Pa. 
The usual problem that has arisen under the discovery procedure has been the attempt of the plaintiff to obtain information concerning employees other than those named as plaintiffs or named as employees on behalf of whom the action has been brought. The courts have uniformly rejected such endeavors on the part of plaintiffs to gain information concerning employees other than those who are parties to the action. ${ }^{101}$ The plaintiff has also been limited to inquiries concerning hours worked, compensation paid and the rate of pay; and discovery with respect to the "type of plaintiffs' employment and the nature of defendant's business activities" ${ }^{102}$ which the court felt could be "more easily established by testimony at the trial . . ." 103 has been denied. Thus, pre-trial discovery has not been helpful to the plaintiff in enabling him to prove facts relating to engagement in interstate commerce. $^{104}$

In the state courts where discovery procedures are available, they have been used in much the same fashion as in the federal courts, and with similar results. ${ }^{105}$

\section{B. At Trial}

The use of the subpoena duces tecum to produce the necessary evidence at the trial has raised an interesting question. May the plaintiff subpoena the employer's correspondence with the Wage and Hour Administration? The courts have denied the use of a subpoena for that purpose. ${ }^{106}$ The theory of the denial is that the correspondence is privileged and to use it for private purposes would interfere with the federal administration of the FLSA. ${ }^{107}$

\section{DefEnses}

It is apparent that a complete denial of the plaintiff's allegations is the best defense. However, in many cases this is not possible. There-

Ior. Mason v. Refiners Transport \& Terminal Corp., to C. C. H. Lab. Cas. $\Uparrow 62,883$ (N. D. Ohio, I945); Shain v. Armour \&.Co., 40 F. Supp. 488 (W. D. Ky. I94I).

102. Mason v. Refiners Transport \& Terminal Corp., 10 C. C. H. Lab. Cas. I 62,883 (N. D. Ohio, I945). Accord: Garbrandt v. Strawn, Io C. C. H. Lab. Cas. $\| 62,884$ (N. D. Ohio, 1945).

I03. Mason v. Refiners Transport \& Terminal Corp., ro C. C. H. Lab. Cas. If 62,883, \68,466 (N. D. Ohio, I945).

104. Scaglione v. Guaranteed Printing Service Co., Inc., ro C. C. H. Lab. Cas. \62,792 (S. D. N. Y. I945); cf. Swoboda v. Carton Finishers, Inc, iI C. C. H. Lab. Cas. If 63,417 (N. D. IIl. 1946).

I05. See Schlein v. Metzger, to C. C. H. Lab. Cas. $\int 62,905$, II4 N. Y. L. J. 592 (Sup. Ct. 1945) (pre-trial examination of employer granted); Bernstein v. Mercantile Ship Repair Co., Inc., ro C. C. H. Lab. Cas. II 62,803, II4 N. Y. L. J. 93 I (N. Y. City Ct. 1945) (motion to inspect books, time records, and payrolls, granted).

106. Davis v. Salter Mills Co., 7 C. C. H. Lab. Cas. If 6r,820 (D. Mass. 1943); Pentland v. Dravo Corp., 4 F. R. D. 305 (W. D. Pa. I945), rev'd on other grounds,

I52 F. (2d) 851 (C. C. A. 3d, I945).

ro7. Shallow v. Markert Mfg. Co., 175 Misc. 6r3, 24 N. Y. S. (2d) 823 (Sup. Ct. 194I). Accord: Fowkes v. Dravo Corp., 5 F. R. D. 5I (E. D. Pa. 1945) (same rule applied to Treasury Department information). 
fore of necessity, defendants have invoked a series of defenses, each of which will be considered separately.

\section{A. Payment 108}

Payment is not a valid defense unless the answer alleges payment in full when due in accordance with the Act. ${ }^{109}$ Payment, after the FLSA wage was due has been held insufficient compliance with the Act. ${ }^{110}$ It follows, therefore, that an offer at the trial to pay any amount less than the full claim plus liquidated damages is futile. ${ }^{111}$

\section{B. Release, Settlement, Accord and Satisfaction}

In Brooklyn Savings Bank v. O'Neil ${ }^{112}$ Mr. Justice Reed, for the Supreme Court, with three justices dissenting, held that the FLSA created rights in employees, which rights were affected with a public interest, and that consequently a written release of such rights without payment for the full amount due thereunder was invalid.

It is now well established that a release, as such, whether in the form of an accord and satisfaction, ${ }^{113}$ covenant not to sue, ${ }^{114}$ a signed account stated, ${ }^{115}$ or general discharge of liability ${ }^{116}$ does not constitute a valid defense. ${ }^{117}$

I08. Payment in full should properly be used as a denial and not as an affirmative defense. Paul v. Greenwich Sav. Bank, 9 C. C. H. Lab. Cas. I 62,393, II2 N. Y. L. J. III3 (N. Y. City Ct. I944). For discussion of general denial see Burke v. Mesta Machine Co., 5 F. R. D. 134 (W. D. Pa. I946).

109. Caperna v. Williams-Bauer Corp., 47 N. Y.. S. (2d) 328 (Sup. Ct. I944), rev'd on other grounds, I84 Misc. 192, 53 N. Y. S. (2d) 295 (Sup. Ct. 1945); cf. Guess v. Montague, 6 C. C. H. Lab. Cas. If 6I,467 (E. D. S. C. I942).

IIo. Caperna v. Williams-Bauer Corp., 47 N. Y. S. (2d) 328 (Sup. Ct. I944), rev'd on other grounds, I84 Misc. I92, 53 N. Y. S. (2d) 295 (Sup. Ct. I945); Gould v. Matam Corp., io C. C. H. Lab. Cas. I 62,932, II4 N. Y. L. J. 582 (N. Y. Sup. Ct. r945), aff'd zeithout opinion, 270 App. Div. 848, 6I N. Y. S. (2d) 389 (Sup. Ct. 1946). See also DePasquale v. Williams-Bauer Corp., I5I F. (2d) 578 (C. C. A. 2d, I945).

III. Madđrix v. Dize, 8 C. C. H. Lab. Cas. If 62,II6 (D. Md. I944), aff'd, 324 U. S. 697 (I945) ; Colan v. Wecksler, 45 F. Supp. 508 (S. D. N. Y. I942) (overtime compensation paid into court). Overpayment is a valid defense. Farrell v. Simons, Inc., 9 C. C. H. Lab. Cas. ๆ 62,410 (D. Minn. I944).

II2. 324 U. S. 697 (1945).

II3. Simmons v. Straight Improvement Co., Inc., 9 C. C. H. Lab. Cas. If 62,394 (S. D. N. Y. I944).

II4. Timberiake v. Day \& Zimmerman, Inc., 49 F. Supp. 28 (S. D. Iowa, 1943).

II5. DePasquale v. Williams-Bauer Corp., I5I F. (2d) 578 (C. C. A. 2d, I945).

Ir6. Watkins v. Hudson Coal Co., I5I F. (2d) 3Ir (C. C. A. 3d, I945), cert. denied, 327 U. S. 777 (1946); Asselta v. I49 Madison Ave. Corp., II C. C. H. Lab. Cas. T63,212 (C. C. A. 2d, 1946) ; Birbalas v. Cuneo Printing Industries, I40 F. (2d) 826 (C. C. A. 7th, 1944); Rigopoulos v. Kervan, I40 F. (2d) 506 (C. C. A. 2d, I943); Fiedler v. Potter, I80 Tenn. 176, 172 S. W. (2d) I007 (I943); Lantinberg v. DiDomenico, to C. C. H. Lab. Cas. I 62,691 (N. Y. Sup. Ct. 1945).

II7. In Franz v. 48 West 48th St. Realization Corp., 60 N. Y. S. (2d) I60 (N. Y. City $\mathrm{Ct}$. I946) the court rejected the contention that the employees cannot bring action unless they first repay the sums paid in consideration of the release. 


\section{Where Bona Fide Dispute Exists}

In the Brooklyn Bank case the question of a release given where a bona fide dispute existed was not raised. The question did arise, however, in D. A. Schulte, Inc. v. Gangi ${ }^{118}$ where an honest dispute existed as to whether the employees were covered by the Act. Full payment of overtime compensation due was made and a release in full was executed. Thereafter an employee sued for liquidated damages. The Supreme Court, in an opinion by Mr. Justice Reed, with three justices dissenting, ${ }^{119}$ held that the release was invalid as a defense. The theory of the Court is that any variation in the sums payable "thwarts the public policy" 120 of the Act.

The Court specifically pointed out that "we need [not] . . . consider here the possibility of compromises in other situations which may arise, such as a dispute over the number of hours worked or the regular rate of employment." 121

Thus it seems clear that although there may be a dispute, if it can be resolved by simple arithmetic a release will be disregarded..$^{122}$ However, the thorny question that arises is the effect of the release where the employee and employer are engaged in an honest dispute over the amount of overtime worked. Several courts have indicated that in such case the release will be regarded as valid. ${ }^{123}$ If this rule is hedged in with safeguards against a mere recital of a dispute, it would seem to be a reasonable solution to the problem. Any other rule would require a complete trial in every case involving a dispute of fact.

118. 66 Sup. Ct. 925 (1946).

II9. JJ. Frankfurter and Burton dissented. C. J. Stone participated in the hearing and disposition of the case and had joined in the dissent prior to his death 66 Sup. Ct. 925, 932 (I946).

r20. Id. at 929.

I2I. Id. at 928.

122. Wathins v. Hudson Coal Co., I51 F. (2d) 311 (C. C. A. 3d, I945), cert. denied, 327 U. S. 777 (1946).

r23. David v. Atlantic Co., 69 Ga. App. 643, 26 S. E. (2d) 650 (1943) ; Withers v. Herbert McLean Purdy Management Corp., 18I Misc. 724, 47 N. Y. S. (2d) 260 (Sup. Ct. I944). Accord: Atlantic Co. v. A. Broughton, I46 F. (2d) 480 (C. C. A. 5th, 1944), cert. denied, 324 U. S. 883 (1945) ; Birbalas v. Cuneo Printing Industries, I 40 F. (2d) 826 (C. C. A. 7th, 1944); Phelan v. Carstens, Linnekin \& Wilson, 187 Misc. 352,62 N. Y. S. (2d) 214 (N. Y. Mun. Ct. I946). See also Cassese v. Manufacturers Trust Co., I82 Misc. 344,46 N. Y. S. (2d) 621 (N. Y. City Ct. I943), where the defendant was a trustee under the supervision of the court and the settlement was approved by the court. Held, not a valid defense. If the court approves a settlement that is extremely unfair to the employee it may raise the question of the power of the court to bargain away the public interest. That courts may, on occasion, be subject to such practices, see Easley v. Edgord Realty Corp., 270 App. Div. I84, 59 N. Y. S. (2d) 24I (Ist Dept. I945), aff'd, 296 N. Y. 579 (1946) where, prior to suit, defendant paid plaintiff \$r58.22 which purported to be payment in full of liability under Act. Poe v. Phelps Dodge Corp., 9 C. C. H. Lab. Cas. T 62,656 (D. Ariz. I944); Strand v. Garden Valley Telephone Co., 5I F. Supp. 898 (D. Minn. I943). Contra: Paul v. Greenwich Sav. Bank, 9 C. C. H. Lab. Cas. $\pi 62,393$, Ir2 N. Y. L. J. III3 (N. Y. City Ct. I944); see Fleming v. Post, 146 F. (2d) $44 \mathrm{I}$ (C. C. A. 2d, 1944). 


\section{Settlements Under Judicial Supervision}

A possible solution to the problem of settling factual controversies under the FLSA is to require all settlements, since a public right is involved, to be judically supervised. A few courts have indicated that such settlements will be binding. ${ }^{124}$ However, other courts have refused to approve private settlements. ${ }^{125}$ Court-supervised settlements must be differentiated from settlements made under the aegis of the Administrator of the Wage and Hour Administration, which are not a bar. ${ }^{126}$

\section{Estoppel}

Ingenious defense attorneys have developed a series of defenses that have uniformly been stricken down by the courts. The cry of "estoppel" has been heard often and lustily but has rarely been accepted. Thus the employee is not estopped because of a failure to make a demand, ${ }^{127}$ or because he accepted his pay checks and misrepresented the hours worked and the employer relied upon the misrepresentation. ${ }^{128}$ However, where the plaintiff-employee was in full charge of the payroll and failed to credit himself with proper payments he was held estopped from claiming additional compensation under the Act. ${ }^{129}$ The court pointed out that here the employee is bound to make claim for overtime to give the employer an opportunity to rectify the situation and avoid liquidated damages.

\section{Custom or Contract}

Neither custom nor contract, pleaded by the defendant, will avail as a defense. ${ }^{130}$ The plea of the existence of a collective bargaining contract has therefore not received much consideration by the courts. Without

124. Allen v. Fred Harvey Service, Ir C. C. H. Lab. Cas. 163,399 (N. D. Ill. I946) ; Morol v. Harry Thoens \& Co., Inc. 63 F. Supp. I88 (S. D. N. Y I945). Contra: Lower court gave plaintiff judgment for $\$ 158.22$ and $\$ 75.00$ counsel fee. Appellate court held release not effective to bar suit, reversed judgment of lower court and awarded judgment of $\$ 4,392.92$, costs and an attorney's fee of $\$ 350.00$.

125. Rogan v. Essex County News Co., Inc., 65 F. Supp. 82 (D. N. J. I946) ; Mariano v. Air Express International Agency, Inc., 9 C. C. H. Lab. Cas. đI 62,606 (S. D. N. Y. 1945).

126. Rigopoulos v. Kervan, I40 F. (2d) 506 (C. C. A. 2d, I943) ; Strand v. Garden Valley Telephone Co., 5 I F. Supp. 898 (D. Minn. I943); Katz v. Film Metal Box Corp., 18I Misc. 812, 47 N. Y. S. (2d) 454 (N. Y. City Ct. 1944).

I27. Bloch v. Bell, 63 F. Supp. 863 (W. D. Ky. 1945), aff'd and rem'd on other grounds, 152 F. (2d) 962 (C. C. A. 6th, 1946).

128. Gatliff Coal Co. v. Cox, I52 F. (2d) 52 (C. C. A. 6th, 1945); DePasquale v. Williams-Bauer Corp., I5I F. (2d) 578 (C. C. A. 2d, I945); Lewis v. Nailing, 36 F. Supp. I87 (W. D. Tenn. I940); Caperna v. Williams-Bauer Corp., 47 N. Y. S. (2d) 328 (Sup. Ct. 1944), rej'd on other grounds, 184 Misc. 192, 53 N. Y. S. (2d) 295 (Sup. Ct. 1945).

I29. Cotten v. Weyerhauser Timber Co., 20 Wash. 300, I47 P. (2d) 299 (1944).

I30. Tennessee Coal, Iron \& Railroad Co. v. Muscoda Local No. I23, 321 U. S. 590 (1944); Anderson v. Mt. Clemens Pottery, Inc., 66 Sup. Ct. I187 (1946). 
attempting to develop the types of contracts upheld and those stricken down-a full topic in itself - it may be said that a collective bargaining contract contrary to the FLSA is no defense to an employees' suit. ${ }^{181}$ Even an agreement entered into pursuant to the recommendation of the National War Labor Board has been held insufficient as a defense. ${ }^{132}$

\section{E. Statute of Limitations ${ }^{133}$}

Congress, in enacting the FLSA, failed to provide a statute of limitations, and the applicable state statute has therefore been held to apply. ${ }^{184}$ The primary problem that has arisen under the state statutes of limitations has been the nature of the FLSA claim, and which of several state statutes of limitation should apply. Most courts have held that a claim under the FLSA is basically contractual and that therefore the state statute limiting contract actions governs. ${ }^{135}$ However, where there is a specific statute governing liability. created by statute that legislation has been held to govern. ${ }^{136}$

Attempts to urge the applicability of state statutes governing penalties have been almost universally unsuccessful. ${ }^{137}$ However, despite the recent pronouncement of the Supreme Court that the liquidated damages payable under the Act "are compensation, not a penalty or punishment by the government," 138 it has been held that the action is divisible, that portion consisting of overtime compensation and reasonable attorney's fees being contractual, and the liquidated damages constituting a penalty so that a penalty statute of limitations governed. ${ }^{138}$

I3r. Watkins v. Hudson Coal Co., I5I F. (2d) 3II (C. C. A. 3d, 1945), cert. denied, 327 U. S. 777 (1946); Dillon $\nabla .247$ Corporation, 7 C. C. H. Lab. Cas. fl 6r,690 (S. D. N. Y. I943) ; Walsh v. 515 Madison Ave. Corp., 18x Misc. 219, 42 N. Y. S. (2d) 262 (Sup. Ct I943), aff'd (no opinion), 267 App. Div. 756 (Ist Dept. I943), aff'd (no opinion), 293 N. Y. 826 (I944). See also Mallory v. United Biscuit Co. of America, ro C. C. H. Lab. Cas. 162,769 (Ohio C. P. 1945).

132. Asselta y. I49 Madison Ave. Corp., to C. C. H. Lab. Cas. I62,907 (S. D. N. Y. I946), aff'd, II C. C. H. Lab. Cas. I 63,212 (C. C. A. 2d, 1946).

133. For a thorough study of this subject see Note (1945) 45 CoL. I. REv. 444.

134. Reliance Storage \& Inspection Co. v. Hubbard, 50 F. Supp. ror2 (W. D. Va. 1943) ; Klatz v. Ippolito, 40 F. Supp. 422 (S. D. Tex. I94I).

135. Smith v. Continental Oil Co., 59 F. Supp. 9r (E. D. N. Y. 1945); Keen v. Mid-Continent Petroleum Corp., 58 F. Supp. g15 (N. D. Iowa, I945) ; Cuniningham v. Weyerhauser Timber Co., 52 F. Supp. 654 (W. D. Wash. 1943); Reliance Storage \& Inspection Co. v. Hubbard, 50 F. Supp. ror 2 (W. D. Va. I943).

I36. Ballard v. Consolidated Steel Corp., Itd., 61 F. Supp. 996 (S. D. Cal. 1945); Cannon v. Miller, 22 Wash. (2d) 227, 155 P. (2d) 500 (1945). Contra: Cunningham v. Weyerhauser Timber Co., 52 F. Supp. 654 (W. D. Wash. 1943).

137. Culver v. Bell \& Loffland, 146 F. (2d) 29 (C. C. A. 9th, 1944); Asselta v. 149 Madison Ave. Corp., ro C. C. H. Lab. Cas. If62,907 (S. D. N. Y. 1945), aff'd, ir C. C. H. Lab. Cas. Tा 63,212 (C. C. A. 2d, 1946); Hargrave v. Mid-Continent Petroleum Corp., 36 F. Supp. 233 (E. D. Okla. I94I), aff'd, 129 F. (2d) 655 (C. C. A. 2d, 1942) ; Reliance Storage \& Inspection Co. v. Hubbard, 50 F. Supp. Ior2 (W. D. Va. 1943).

I38. Overnight Motor Transportation Corp. v. Missel, 3I6 U. S. 572 (I942).

139. Southern Package Corp. v. Walton, Admx., Igك Misc. 786, I8 So. (2d) 458 (1944), cert. denied, 323 U. S. 762 (1944) (the attorney's fee was held governed by 
Eleven states have enacted statutes of limitations intended to cut off FLSA actions. ${ }^{140}$ Some of these statutes have been discriminatory or unusually harsh and have, consequently, failed to meet the test of constitutionality. ${ }^{141}$ However, this subject will probably soon become academic ${ }^{142}$ in view of the likelihood of early enactment of a Federal Statute of Limitations for FLSA claims. At the last session of Congress ${ }^{143}$ four bills were introduced. One of these, ${ }^{144}$ introduced by Representative Gwynne, provided for a two year limitation upon actions. The time limitation was amended by the Senate to three years. ${ }^{145}$ However, the session of Congress ended before agreement could be reached. The probability is that the next session will pass a limitations act. ${ }^{146}$ It is to be hoped that the limitations imposed will not be harshly brief. ${ }^{147}$

\section{F. Violation of the Act Caused by Employee's Conduct}

It is a valid defense to an employee's claim under the FLSA that the violation of the Act was caused solely by the employee. Thus, where an employee of his own volition works overtime without the knowledge of the employer ${ }^{148}$ or in violation of instructions issued by the employer ${ }^{149}$ the employer will not be liable. However, the defense must be bona fide and if the employer is aware of the overtime

the contract statute of limitations). This was also the holding in Culver v. Bell \& Loffland, Inc., 8 C. C. H. Lab. Cas. $\Uparrow 62,025$ (S. D. Cal. 1943), which was reversed 146 F. (2d) 29 (C. C. A. 9 th, I944).

I40. Note (1945) 45 CoL. L. REv. 444, 448.

I4I. Republic Pictures Corp. v. Kappler, 15 I F. (2d) 543 (C. C. A. 8th, 1945), aff'd, 327 U. S. 757 (1946); E. H. Clarke Lumber Co. v. Kurth, I52 F. (2d) 914 (C) C. A. 9th, 1945) ; Davis v. Rockton \& Rion R. R., 65 F. Supp. 67 (W. D. S. C. 1946); Fullerton v. Lamm, 163 P. (2d) $94 \mathrm{r}$ (Ore. 1945), aff'd on rehearing, I65 P. (2d) 63 (Ore. 1946 ).

r42. Some of the problems will remain. For example, see Phelan v. Carstens, Linnekin \& Wilson, 62 N. Y. S. (2d) 214 (N. Y. Mun. Ct. I946), in which it was held that payment of overtime due but not liquidated damages constituted an acknowledgment of the debt which caused the statute of limitations to cease running and to begin anew from time of acknowledgment. See also Hayes v. Cuneo Printing Industries, Inc., II C. C. H. Lab. Cas. II 63,339 (N. D. I11. I946) holding that part payment tolled the statute of limitations.

I43. H. R. 2788; H. R. 3079; Sen. 1013; Sen. 750, 79th Cong., 2d Sess. (1946).

144. H. R. 2788, 79th Cong., 2d Sess. (1946).

145. I8 Lab. Rel. Rep. (loose Leaf) I277 (1946).

146. See Phila. Legal Intelligencer, Dec. 17 , 1946, p. 6, col. 2 (Limitation of Employer's Liability Before Congress). Ibid.

147. The Department of Labor recommends a three year statute of limitations.

148. Anderson v. Sunbright Lumber Co., 7 C. C. H. Lab. Cas. $\pi 61,632$ (Tenn. Ct. App. I943); see Pioneer Corp. v. Kinsey, I96 Okla. 89, I62 P. (2d) 1000 (1945).

149. Ortiz v. San Juan Dock Co., Inc., ro C. C. H. Lab. Cas. I 62,789 (D. Puerto Rico, I945); Stein v. Gorden Bros. Mfg. Co., 43 F. Supp. 249 (W. D. Mo. 1942); Mabee Oil \& Gas Co. v. Thomas, I95 Okla. 437, r58 P. (2d) 7r3 (I945); West v. Cleveland Overall Co., 4 C. C. H. Lab. Cas. $\mid 60,671$ (Cleveland Mun. Ct. I94I). 
he is liable under the Act. ${ }^{150}$ Indeed, the argument that the employee was a volunteer, working without compensation, has been rejected as a defense to a minimum wage suit since the Act created liability so long as the employee has been "suffered or permitted" to work. ${ }^{151}$

Where an employee is responsible for keeping records of overtime a cause of action will not arise out of the employee's having kept erroneous records; ${ }^{152}$ but, if the employer conspires with the employee to keep false records, the employer remains liable. ${ }^{153}$ Thus, an employee may contradict a signed time sheet. ${ }^{154}$ In reply to the contention that in these cases the employee should be barred because he is in pari delicto with the employer, one court ${ }^{155}$ explained by quoting Lord Ellenborough:

"This is not a case of par delictum: it is oppression on one side, and submission on the other: it can never be predicated as par delictum, when one holds the rod and the other bows to it." 168

\section{G. Mental State}

The mental attitude of the employer is clearly irrelevant. Thus good faith and a lack of intent to violate the Act do not comprise valid defenses. ${ }^{157}$ Therefore, payment in accordance with a directive of the Administrator of the Wage and Hour Division does not relieve an employer from liability for liquidated damages. ${ }^{158}$ Nor will a collective bargaining contract written under the mutual mistake of law that the contract conformed to the Act prevent any employee from recovering full statutory liability. ${ }^{159}$

I50. Kappler v. Republic Pictures Corp., 59 F. Supp. 112 (S. D. Iowa 1945), aff'd, 327 U. S. 757 (I946); Quillen v. Shapiro, 5 C. C. H. Lab. Cas. đ6 60,9r5 (M. D. Tenn. I94I) ; Steger v. Beard \& Stone Electric Co., 4 C. C. H. Lab. Cas. f 60,643 (N. D. Tex. I94I). See also Prentice-Hall Wage and Hour Service, II ro,3r3.ro.

I5I. Rogers v. Schenckel, II C. C. H. Lab. Cas. T63,43I (W. D. N. Y. 1946).

152. Bergschneider v. Peabody Coal Co., I42 F. (2d) 784 (C. C. A. 7th, 1944); Mortenson v. Western Light \& Telephone Co., 42 F. Supp. 319 (S. D. Iowa, I94I); Cotten v. Weyerhauser Timber Co., 20 Wash. 300, I47 P. (2d) 299 (I944). Contra: Travis v. Ray, 4I. F. Supp. 6 (W. D. Ky. I94I).

153. Gosinski v. Eclipse Glass Co., Inc., I3 Conn. Sup. 285 (Conn. C. P. Ct. r945); Butler v. Carter, 32 S. E. (2d) 808 (Ga. I945).

154. Wilson Oil Co. v. Hardy, 49 N. Mex. 337, I64 P. (2d) 209 (1945).

I55. Gosinski v. Eclipse Glass Co., Inc., I3 Conn. Sup. 285 (Conn. C. P. Ct. I945).

I56. Smith v. Cuff, 6 M. \& S. I60, I05 Eng. Reprint I203 (I8I7).

I57. Clarke v. I26 Fifth Ave. Corp., 8 C. C. H. Lab. Cas. I 62,018, \62,084 (S. D. N. $\dot{\mathrm{Y}}$. 1944); Missel y. Overnight Motor Transportation Co., Inc., I26 F. (2d) 98 (C. C. A. 4th, I942), aff'd, 316 U. S. 572 (I942); Wilson Oil Co. v. Hardy, 49 N. Mex. 337, I64 P. (2d) 209 (1945); cf. Andrus v. Harding, 3 C. C. H. Lab. Cas. If 60,180 (W. D. Tenn. I940).

I58. Seneca Coal \& Coke Co. v. Lofton, I36 F. (2d) 359 (C. C. A. Ioth, I943), cert. denied, 320 U. S. 772 (1943).

159. Yellow Truck \& Coach Mfg. Co. v. Edmondson, II C. C. H. Lab. Cas. I63,150 (C. C. A. 6th, 1946). 


\section{H. Res Judicata}

One complete judicial adjudication will bar a second suit between the parties under the FLSA. ${ }^{160}$ However, the few cases that have arisen under this defense have usually involved fact situations in which the court found an absence of res judicata. For example, it has been held that a decree, in an injunction suit brought by the Administrator of the Wage and Hour Division, in favor of the employer will not bar a subsequent suit by an employee against that employer. ${ }^{16 I}$ In another case, ${ }^{162}$ an employee intervened in a suit by a fellow employee but never had an opportunity to produce evidence or prove his case; he was held not barred from bringing an action of his own. These cases illustrate the application to FLSA suits of the general rule that each person is entitled to his full day in court before being barred forever. ${ }^{163}$ Therefore, employees who are not plaintiffs or intervenors, or who did not authorize suit in their behalf will not be bound by the judgment in the action. ${ }^{164}$

\section{Miscellaneous Defenses}

A series of other defenses will be briefly presented.

I. The fact that the work for which recovery is sought is performed in a foreign country is a valid defense. ${ }^{165}$

2. That the work was upon or in connection with property of the Federal Government is immaterial. ${ }^{166}$

3. Acceptance of an amount paid pursuant to a judgment bars further appeals. ${ }^{167}$

I60. Berrios v. Baetjer, 6 C. C. H. Lab. Cas. If6I,I4I (D. Puerto Rico I942). In D. \& L. Production Co. v. Cuniff, I80 S. W. (2d) 205 (Tex. Civ. App. 1944) a prior suit for unpaid wages, not brought under the FLSA was held to bar a subsequent suit for overtime under the FLSA.

I6r. Katz v. Film Metal Box Corp., I8I Misc. 8I2, 47 N. Y. S. (2d) 454 (N. Y. City Ct. I944).

162. Burns v. Gilfin, 182 Tenn. 535, 188 S. W. (2d) 338 (I945).

163. See Restatement, Judgments (I942) § I, Comment b.

164. Brooks v. Southern Dairies, Inc., 38 F. Supp. 588 (S. D. Fla. I94I). Accord: Clougherty v. James Vernor Co., Io C. C. H. Lab. Cas. II 62,704 (E. D. Mich. I945); Timberlake v. Day \& Zimmerman, Inc., 49 F. Supp. 28 (S. D. Iowa, I943); Thomas v. Keystone Silver, Inc., 174 Misc. 733, 22 N. Y. S. (2d) 796 (N. Y. Sup. Ct. 1940); see Keyes v. Hope Estates, Inc., 53 F. Supp. 1004 (S. D. N. Y. 1943). Contra: Cissell v. Great Atlantic \& Pacific Tea Co., 37 F. Supp. 913 (W. D. Ky. I94I).

165. Connell v. Vermilya-Brown Co., II C. C. H. Lab. Cas. Il 63,39I (S. D. N. Y. 1946); Greenstein v. Pan American Airways, Inc., 9 C. C. H. Lab. Cas. II 62,626, II3 N. Y. L. J. I520 (Sup. Ct. I945) ; Filardo v. Foley Bros., Inc., I8I Misc. 136, 45 N. Y. S. (2d) 262 (Sup. Ct. I943).

166. Connell v. Vermilya-Brown Co., II C. C. H. Lab. Cas. I 63,39I (S. D. N. Y. 1946) ; Ortiz v. San Juan Dock Co., Inc., to C. C. H. Lab. Cas. \62,789 (D. Puerto Rico, r945).

I67. Colquette v. Crossett Lumber Co., I49 F. (2d) II6 (C. C. A. 8th, I945). 
4. A counterclaim, if all procedural difficulties are resolved, may be used as a defense. ${ }^{168}$

\section{TRIAL \\ A. Burden of Proof \\ I. Interstate Commerce}

As is customary, the plaintiff must carry the burden of proving the essential facts in an FLSA case. ${ }^{168}$ Thus, he must prove his engagement in interstate commerce or in the production of goods for commerce. $^{170}$ The cautious plaintiff will introduce evidence of the interstate commerce nature of his work even though everyone, including the trial court, appears to assume it. In one case, ${ }^{171}$ at least, although the trial court assumed engagement in interstate commerce, the appellate court reversed because of absence of facts relating thereto in the record. If a stipulation is used, it should be complete. Where by stipulation the parties agreed that $27 \%$ of defendant's products went into interstate commerce the court refused to conclude therefrom that each plaintiff, in a group action, spent $27 \%$ of his activities on behalf of the employer in interstate commerce. ${ }^{172}$

However, despite the apparent tendency of these cases the courts have not imposed too great a burden of proof with respect to interstate commerce upon employees in FLSA cases. Thus, where an employee showed that his work was both in inter- and intra-state commerce it was held that if, as the employer claimed, during certain of the workweeks the employee's work was confined solely to intra-state commerce, the burden rested upon the employer to prove such facts since they would be peculiarly within his knowledge. ${ }^{173}$

I68. Scaglione v. Guarantee Printing Service Co., Inc., ro C. C. H. Lab. Cas. I62,734, $\llbracket 62,792$ (S. D. N. Y. I945). The employee's suit may also arise by way of counter-claim. Smoke Mt. Ind., Inc. v. Fisher, 224 N. C. 72, 29 S. E. (2d) 128 (1944).

169. E. g., plaintiff must prove defendant was statutory employer. Parenti v. Kalamazoo Stove \& Furnace Co, II C. C. H. Lab. Cas. If 63,354 (Conn. C. P. Ct. 1946).

170. Schwarz v. Witwer Grocer Co., 49 F. Supp. I003 (N. D. Iowa 1943), aff'd, I4I F. (2d) 34I (C. C.A. 8th, 1944), cert. denied, 322 U. S. 753 (1944); Ullo v. Smith, 62 F. Supp. 757 (S. D. N. Y. I945); Lyons v. A. K. Ferguson Co., 16 So. (2d) 587 (La. App. I944). (1944).

I7r. Grippentrog v. Cheese Makers' Mfg. Co., 245 Wis. I, I3 N. W. (2d) 391 I945).

172. Cody v. Dossin's Food Products, to C. C. H. Lab. Cas. $\llbracket 62,785$ (E. D. Mich.

I73. Guess v. B. L. Montague, I40 F. (2d) 500 (C. C. A. 4th, 1943). See also Tucker v. Hitchcock, 42 F. Supp. 874 (S. D. Fla. I942), 56 HARv. L. REv. 140. But where employer can show different facts concerning interstate commerce for distinct periods recovery will be limited to the period in which the employee was engaged in interstate commerce. Asselta v. I49 Madison Ave. Corp., Io C. C. H. Lab. Cas. \62,907 (S. D. N. Y. I945), aff'd, II C. C. H. Lab. Cas. \63,212 (C. C. A. 2d, I946). 
The Supreme Court has also lightened the plaintiff's burden with respect to interstate commerce. In a recent case ${ }^{174}$ the court held that the plaintiff sustained his burden where the record showed that the employer had reasonable grounds to anticipate that material quantities of production would move in interstate commerce. It was not essential to trace individual products into the stream of commerce. Moreover, the percentage of interstate activity proved need not be great. Four per cent has been held sufficient; ${ }^{175}$ and so has seven per cent. ${ }^{176}$ However, proof of a mere incidental interstate activity will be held de minimis. ${ }^{177}$

\section{Hours Worked and Rate of Pay}

The general rule is that the plaintiff must prove the number of hours worked and the regular rate of pay. ${ }^{178}$ Thus, the employee cannot prove an overtime claim based upon quantum meruit--there must be a "regular rate of pay." 179

With respect to the number of hours worked it is obvious that the employees cannot prove mathematically precise cases. For a time this caused severe difficulties where courts followed general common law rules requiring precise proof. ${ }^{180}$ However, the Supreme Court in the Walking Time case ${ }^{181}$ set up certain guideposts that will be helpful in all cases. The Court pointed out realistically that imposing a strict standard of proof on the employees would have the "practical effect of impairing many of the benefits" ${ }^{182}$ of the Act and would be contrary to the "remedial nature of this statute and the great public policy which it embodies." ${ }^{83}$ The Court considered the difficulties inherent in proving a case where the only records are inaccurate or inadequate and stated:

174. D. A. Schulte, Inc. v, Gangi, 66 Sup. Ct. 925 (1946).

r75. Southern Calif. Freight Lines v. McKeown, I48 F. (2d) 890 (C. C. A. 9th, I945), cert. denied, 326 U. S. 736 (1946). I944).

176. New Mexico Public Serv. Co. v. Engel, I45 F. (2d) 636 (C. C. A. roth,

177. Porter v. Wilson, 5 C. C. H. Lab. Cas. 160,896 (N. D. Tex. 1942); Morrow v. Lee Baking Co., 4 C. C. H. Lab. Cas. I60,70I (N. D. Ga. I94I); Mile High Poultry Farms, Inc. v. Fraizer, I57 P. (2d) I25, II3 Colo. 338 (I945).

178. Mornford v. Andrews, I5I F. (2d) 5 II (C.C. A. 5th, 1945) ; Bowers v. Remington Rand, Inc., 64 F. Supp. 621 (S. D. I11. 1946).

I79. Schammo v. Ahlskog, 158 Kan. 203, I46 P. (2d) 408 (1944).

I80. Mornford v. Andrews, I5I F. (2d) 5 II (C. C. A. 5 th, 1945); Bloch v. Bell, 63 F. Supp. 863 (W. D. Ky. I945), aff'd, 152 F. (2d) 964 (C. C. A. 6th, I946); Lowrimoore v. Union Bag \& Paper Co., 30 F. Supp. 647 (S. D. Ga. 1939), aff'd, I16 F. (2d) 27 (C. C. A. 5th, 1940), cert. denied, 313 U. S. 559 (I94I); Stewart v. Mabee Oil \& Gas Co., I58 Kan. 388, I47 P. (2d) 73I (I944); Clevenger v. Ritter Lumber Co., 294 Ky. 764, I72 S. W. (2d) 625 (1943). See Note (1943) 43 CoL. L. REv. 355, 356.

18i. Anderson v. Mt. Clemens Pottery Co., 66 Sup. Ct. 1187 (1946).

182. Id. at Ir92.

183. Ibid. 
"The solution, however, is not to penalize the employee by denying him any recovery on the ground that he is unable to prove the precise extent of uncompensated work." 184

The Court then held in a situation where the employee could not prove the precise amount of overtime worked,

“. . . that an employee has carried out his burden if he proves that he has in fact performed work for which he was improperly compensated and if he produces sufficient evidence to show the amount and extent of that work as a matter of just and reasonable inference. The burden then shifts to the employer to come forward with evidence of the precise amount of work performed or with evidence to negative the reasonableness of the inference to be drawn from the employee's evidence. If the employer fails to produce such evidence, the court may then award damages to the employee, even though the result be only approximate." 185

The result would appear to be to remedy the injustices that arose from the inability of employees to prove their cases. Prior to this decision some courts had already worked out a rough and ready method of estimating the amount to be recovered even in the absence of any clear proof of hours of overtime worked. ${ }^{186}$ Recent cases make it clear that the trier of the facts will now only be required to approximate a fair recovery. ${ }^{187}$

\section{Exemptions}

Since the employer's claim that the plaintiff is not covered by the Act because of a specific exemption is an affirmative defense the employer must carry the burden of proving such exemption. ${ }^{188}$ However, the employer sustains his burden by proving a prima facie case

184. Ibid.

185. Ibid.

186. Strough v. Coll, Adm'x, 7 C. C. H. Lab. Cas. I 61,644 (E. D. Pa. 1943); Steger v. Beard \& Stone Electric Co., 4 C. C. H. Lab. Cas. If 60,643 (N. D. Tex. 194I) ; Schanck v. Iehigh Valley Railroad, 52 N. Y. S. (2d) 491 (City Ct. N. Y. I944) ; Emerson v. Mary Lincoln Candies, Inc., Referee's opinion, I74 Misc. 353, 20 N.Y.S. (2d) 570 (Sup. Ct. 1940), aff'd, 26r App. Div. 879, 26 N. Y. S. (2d) 489 (4th Dept. 1941), aff'd, 287 N. Y. 577, 38 N. E. (2d) 234 (1941); Smith v. Ogle, 196 Okla. 295, I64 P. (2d) 992 (1945); see Muldowney v. Seaberg Elevator Co., Inc., $39 \mathrm{~F}$. Supp. 275, 282 (E. D. N. Y. I94I).

187. Johnston v. Firemen's Insurance Co., II C. C. H. Lab. Cas. I6 63,120, II5 N. Y. L. J. 16r4 (Sup. Ct. I946); Asselta v. I49 Madison Ave. Corp., Io C. C. H. Lab. Cas. $\pi 62,907$ (S. D. N. Y. 1946), aff'd, it C. C. H. Lab. Cas. \63,212 (C. C. A. 2d, 1946). Contra: Davies v. Onyx Oils \& Resins, Inc., 63 F. Supp. 777 (D. N. J. 1946).

188. Stanger v. Vocafilm Corp., 15I F. (2d) 894 (C. C. A. 2d, 1945); Distelhorst v. Day \& Zimmerman, Inc., 58 F. Supp. 334 (S. D. Iowa, 1944), dismissed per curiam, 150 F. (2d) 54 I (C. C. A. 8th, 1945); Gibson v. Atlantic Co., 63 F. Supp. 492 (N. D. Ga. I945) ; Burke v. Le Crone-Benedict Ways, Inc., 63 F. Supp. 883 (E. D. Mich. 1945); Cohn v. Decca Distributing Corp., 50 F. Supp. 270 (E. D. Pa. I943). 
and need not rebut exceptions from the exemptions. ${ }^{189}$ For example, the Act exempts "any employee employed in a bona fide executive . . . capacity . . . as defined and delimited by regulations of the Administrator." 190 Under the regulations an employee, who might otherwise be regarded as employed in an executive capacity ceases to be such if more than twenty per cent of the hours worked by such employee is work of the same nature as that performed by nonexempt employees. $^{191}$ In one case ${ }^{192}$ the employer proved that the employee was in fact an "executive" as defined by the Administrator. It was held to be the employee's burden to show, if he desired and could, that he came within the twenty per cent exception.

\section{B. Evidence}

\section{Oral}

Unquestionably the plaintiff must produce evidence ${ }^{193}$ of a credible nature ${ }^{194}$ to support his allegations. His failure to do so is fatal. Regarding this point it is difficult to generalize. Of course, there is a statutory duty ${ }^{195}$ upon the employer to keep records and infeasibility is no excuse. ${ }^{196}$ Such records, if complete, can be sufficient to prove plaintiff's case. However, in the majority of those cases where the action is for walking time, waiting time or other unrecorded work time the employer's records are of no value. ${ }^{197}$ In most such cases the employee must prove the case by oral testimony of witnesses. Such testimony has received varied treatment by the courts. The fact that the hours were regular adds weight to the testimony. ${ }^{198}$ The length of time elapsing between the work performed and the trial is considered. ${ }^{199}$

I89. Weeks v. Federal Cartridge Corp, io C. C. H. Lab. Cas. I62,952 (D. Minn. I946); Zaetz v. General Instrument Corp., 7 C. C. H. Lab. Cas. I 6r,570 (D. N. J. I943).

I90. 52 STAT. I067, 29 U. S. C. $2714, \S 213$ (I938).

I9I. Regulations of Wage and Hour Division, $\$ 54$ I.I (Oct. I2, I940), 5 FED. REG. 4077; 29 CODE FED. REG. pt. 54I (Supp. 1940). I943).

192. Zaetz v. General Instrument Corp., 7 C. C. H. Lab. Cas. II61,570 (D. N. J.

I93. Simmons v. Straight Improvement Co., Inc., 9 C. C. H. Lab. Cas. I 62,394 (S. D. N. Y. I944).

I94. Griswold v. Rosenstock, to C. C. H. Lab. Cas. 162,807 (S. D. N. Y. 1945). I95. 52 STAT. 1066, 29 U. S. C. $27 I_{3}, \S 21$ I $^{\prime}$ (1938).

I96. Walling v. Panther Creek Mines, Inc., I48 F. (2d) 604 (C. C. A. 7th, 1945); Walling v. Reilly, 59 F. Supp. 740 (E. D. Pa. 1944).

I97. See, e. g., Anderson v. Mt. Clemens Pottery Co., 66 Sup. Ct. II87 (I946) (time clock records can be used as an appropriate measurement of hours worked only when they accurately reflect periods worked); cf. Hickey v. Davidson Transfer \& Storage Co., II C. C. H. Lab. Cas. $\$ 63,163$ (S. D. N. Y. I946) (recovery allowed for overtime hours as indicated by punched time cards).

I98. Murdick v. Cities Service Oil Co., I45 F. (2d) 23 I (C. C. A. Ioth, I944); Caperna v. Williams-Bauer Corp., 184 Misc. I92, 53 N. Y. S. (2d) 295 (Sup. Ct. 1945).

I99. Toppin v. I2 East 22nd St. Corp., 55 F. Supp. 887 (S. D. N. Y. I944). 
Testimony in which the witnesses were forced to generalize and refer to "average hours worked" has been accepted, where corroborated, ${ }^{200}$ and rejected where standing alone. ${ }^{201}$ This suggests that corroboration is of importance. ${ }^{202}$ However, if the plaintiff's oral evidence is clear and unequivocal recovery usually follows. ${ }^{203}$

\section{Written}

The cases frequently refer to the fact that the employee is under no duty to keep written records. ${ }^{204}$ Nevertheless occasionally employees keep some form of running account of hours worked. Usually such records are rejected as not having been made in the normal course of business, ${ }^{205}$ the customary justification for the "account book exception" to the rule excluding hearsay. ${ }^{200}$ Although some courts have admitted employees' records in evidence, ${ }^{207}$ it would seem better to use the employee's written record as a method of refreshing his memory. This has been permitted. ${ }^{208}$

200. Smith v. Ogle, I96 Okla. 295, I64 P. (2d) 992 (I945).

201. Epps v. Weathers, 49 F. Supp. 2 (S. D. Ga. 1943).

202. See Stewart v. Mabee Oil \& Gas Co., I58 Kan. 388, 147 P. (2d) 731 (1944); Vigiano v. Arena \& Sons, Inc., 8 C. C. H. Lab. Cas. I 62,058, III N. Y. L. J. 927 (Sup. Ct. I944), where in absence of corroboration the plaintiffs were denied recovery. Especially is this true if defendant rebuts plaintiff's evidence. Randolph v. Calamus, 9 C. C. H. Lab. Cas. If 62,520 (S. D. Ga. I944), aff'd, I5I F. (2d) 649 (C. C. A. 5th, 1945).

203. DePasquale v. Williams-Bauer Corp., I5I F. (2d) 578 (C. C. A. 2d, 1945), cert. denied, 66 Sup. Ct. I007 (I946); Edwards v. South Side Auto Parts Co., 180 S. W. (2d) Ior 5 (Mo. App. 1944); Kessler v. Cliff Frocks, Inc., I84 Misc. 56r, 56 N. Y. S. (2d) I64 (Sup. Ct. r945). See Parenti v. Kalamazoo Stove \& Furnace Co., II C. C. H. Lab. Cas. \6 63,354 (Conn. I946).

204. Ballard v. Consolidated Steel Corp., Ltd., 6r F. Supp. 996 (S. D. Cal. 1945). See also DePasquale v. Williams-Bauer Corp., I5I F. (2d) 578 (C. C. A. 2d, I945), cert. denied, 66 Sup. Ct. 1007 (1946); Smith v. Ogle, 196 Okla. 295, 164 P. (2d) 992 (1945); cf. Stein v. Gorden Bros. Mfg. Co., 43 F. Supp. 249 (W. D. Mo. 1942) where, because plaintiff was an attorney, the court imposed the burden of keeping records.

205. Jackson v. Pioneer Adhesive Works, Inc., I32 N. J. L. 397,40 A. (2d) 634 (Sup. Ct. N. J. I945). Accord: Suffron v. Street Bros. Construction Co., Inc., ro C. C. H. Lab. Cas. \62,87I (N. D. N. Y. 1945); Sherman v. Solomon, 9 C. C. H. Lab. Cas. II 62,57I, II3 N. Y. L. J. 9I3 (N. Y. City Ct. I944). One employer's subsequent records have also been denied admission. Kessler v. Cliff Frocks, Inc., I84 Misc. $56 \mathrm{x}, 56$ N. Y. S. (2d) I64 (Sup. Ct. I945).

206. See McKelvey, Evidence (5th ed. 1944) \$247. This rule would appear to render admissible a building custodian's records and so the courts have held. Burke v. LeGrone-Benedict Ways, Inc., 63 F. Supp. 883 (E. D. Mich. 1945); Pretto v. South American Trading Corp., II5 N. Y. L. J. 1462 (N. Y. City C.t 1946).

207. Sapp v. Baird-Naundorf Lumber Co., io C. C. H. Lab. Cas. I 62,999 (Wash. Super. Ct. 1946); Colon v. Distilleries V. M. Ramirez \& Cia., 9 C. C. H. Lab. Cas. I 62,64I (D. Puerto Rico, I945); Allen v. Moe, 39 F. Supp. 5 (D. Idaho, I94I); Wilson Oil Co. v. Hardy, 49 N. Mex. 337, I64 P. (2d) 209 (1945). In Straughn v. Schlumberger Well Surveying Corp., II C. C. H. Lab. Cas. II 63,355 (S:D. Tex. I946) the employee's records made for the employer were admitted in evidence despite employer's contention that the records were not accurate.

208. Fanelli v. United States Gypsum Co., r4I F. (2d) 216 (C. C. A. 2d, I944); Lawley \& Son Corp. v. South, I40 F. (2d) 439 (C. C. A. Ist, I944). 


\section{Defensive Evidence}

Recent cases have raised interesting questions concerning defensive evidence. In a Nebraska case ${ }^{209}$ the question arose whether an employee's written release was admissible in evidence. The court sustained the admissibility as an admission against interest. In view of the circumstances, the court may have been correct since the defense was that the employee was exempt and the release supported that defense. However, any extension of the rule might weaken the present rigid rule barring the effectiveness of releases-although not valid as defenses they might be used to influence a jury.

A somewhat similar question concerns the admissibility in evidence of the failure of the plaintiff to demand overtime payments prior to termination of his employment. Two cases have held that evidence of the failure to make such demand is admissible. ${ }^{210}$ This ruling appears to be clearly erroneous. The failure to make demand may be caused by ignorance of the FLSA, belief that there is no coverage, fear of losing one's job or a host of other factors. Assuming that it proves that no overtime compensation is due, as one court did, ${ }^{211}$ seems unwarranted.

\section{JUDGMENTS}

\section{A. Verdict}

In view of the non-mathematical nature of the plaintiff's cause of action a round-figure verdict doing substantial justice to plaintiff's evidence will be upheld. ${ }^{212}$ However, if the verdict is simply a compromise it will be set aside ${ }^{213}$ or if the verdict is contrary to the testimony there may be a remittitur. ${ }^{214}$ A judgment notwithstanding the compromise verdict may be granted where such judgments are authorized, as they are, for example, by the Federal Rules. ${ }^{215}$

209. Anderson v. Nebraska Defense Corp., 146 Neb. 466, 20 N. W. (2d) 322 (1945). The reverse aspect of this problem is found in Cunningham v. Davis, 203 Ark. 982 , 159 S. W. (2d) 751 (1942), where the court permitted the employees to introduce evidence showing an offer on the part of the employer to compromise by part payment. 210. Schmidtke v. Conesa, 10 C. C. H. Lab. Cas. If 62,982 (D. Puerto Rico 1946); Foster v. Knopf Mfg. Co., Io C. C. H. Lab. Cas. \62,967 (D. Mass. 1946).

21I. Schmidtke v. Conesa, Io C. C. H. Lab. Cas. 162,982 (D. Puerto Rico I946). 212. Ashenford v. L. Yukon \& Sons Produce Co., 237 Mo. App. I24I, I72 S. W. (2d) 88I (I943); Kessler v. Cliff Frocks, Inc., I84 Misc. 56I, 56 N. Y. S. (2d) 164 (Sup. Ct. 1945).

213. Kirschenbaum v. National Tallow \& Soap Co., 9 C. C. H. Lab. Cas. \62,585, II3 N. Y. L. J. 963 (Sup. Ct. I945).

214. Smith v. Ogle, I96 Okla. 295, I64 P. (2d) 992 (1945). See also Deluca v. West 26th St. Corp., II C. C. H. Lab. Cas. $\pi 63,255$ i16 N. Y. L. J. 74 (N. Y. City Ct. I946).

215. Keen v. Mid-Continent Petroleum Corp., 63 F. Supp. 120 (N. D. Iowa 1945); Riley v. Nutley Dye Works, 8 C. C. H. Lab Cas. đ62,168 (D. N. J. 1943). 


\section{B. Findings of Fact ${ }^{216}$}

The findings of fact of the tribunal vested with the function of making such findings are generally upheld unless clearly erroneous. This rule has been applied to a special master, ${ }^{217}$ to a referee in bankruptcy, ${ }^{218}$ to trial courts, ${ }^{219}$ and to the jury. ${ }^{220}$

\section{Costs}

Costs follow the action. The Act itself provides that "in addition to any judgment awarded to the plaintiff" the court shall allow "costs of the action." 221 This legislative injunction has been followed. ${ }^{222}$ By the same token, when judgment is entered for the defendant costs are assessed against the plaintiff. ${ }^{223}$

\section{Interest}

Before the subject was finally decided by the Supreme Court, many courts allowed interest from the date of the accrual of the action, ${ }^{224}$ or from the date of suit. ${ }^{225}$ However, the Supreme Court has held that the plaintiff may not recover interest because the liquidated damages awarded by the statute are in lieu of interest. ${ }^{228}$ To hold to the contrary, the Court stated, would "produce the undesirable result of allowing interest on interest." 227 Moreover, the Court also held that the

216. So long as any issue of relevant fact remains triable a motion for summary judgment will be denied. Inter-Mountain Iron \& Metal Co. v. Cortinez, II4 Colo. 89, 162 P. (2d) 237 (1945); Franz v. 48 West 48th St. Realization Corp., 60 N. Y. S. (2d) 160 (N. Y. City Ct. 1946).

217. Anderson v. Mt. Clemens Pottery, Inc., 66 Sup. Ct. I187 (1946). 1945).

218. In re George R. Burrows, Inc., ro C. C. H. Lab. Cas. \62,713 (S. D. N. Y.

219. Dumas \& Dumas v. King, II C. C. H. Lab. Cas. $\pi 63,378$ (C. C. A. 8 th, 1946) ; Randolph v. Calamas, I5I F. (2d) 649 (C. C. A. 5th, 1945) ; Engebretsen v. E. J. Albrecht Co., I50 F. (2d) 602 (C. C. A. 7th, 1945); Atlantic Co. v. Weaver, 150 F. (2d) 843 (C. C. A. 4 th, 1945).

220. Swoboda v. Carton Finishers, Inc., ir C. C. H. Lab. Cas. $\| 63,417$ (N. D. I1l. 1946) ; Belcher v. Hubbard, 21 So. (2d) 850 (Ala. App. r945).

221. 52 Stat. 1069 (1938), 29 U. S. C., $\$ 216$ (b) (1940).

222. Cohn v. Decca Distributing Corp., 50 F. Supp. 270 (E. D. Pa. 1943) ; Koerner v. Associated Linen Suppliers Laundry, Inc., 185 Misc. 123, 57 N. Y. S. (2d) 92 (Sup. Ct. I945), aff'd, 62 N. Y. S. (2d) 774, 270 App. Div. 986 (Ist Dept. 1946). 1943).

223. Hinkler v. Eighty-Three Maiden Lane Corp., 50 F. Supp. 263 (S. D. N. Y.

224. Greenberg v. Arsenal Bldg. Corp., I44 F. (2d) 292 (C. C. A. 2d, 1944), rez'd in part, 324 U. S. 697 (r945) ; Kreeft v. Bates Piece Dye Works, 63 F. Supp. 88r (S. D. N. Y. 1945); Steiner v. Pleasantiville Constructors, Inc., 9 C. C. H. Lab. Cas. đ6 62,397, II2 N. Y. L. J. II80 (Sup. Ct. I944)

Pa. 1944).

225. Ackerman v. Baltimore Markets, Inc., 8 C. C. H. Lab. Cas. $\llbracket 62,003$ (E. D. 226. Brooklyn Savings Bank v. O'Neil, 324 U. S. 697 (1945), rehearing denied,

325 U. S. 893 (1945). Accord: Bell v. Bloch, I52 F. (2d) 964 (C. C. A. 6th, 1946). 227. Id. at $7 \mathrm{r2}$. 
right to interest in FLSA cases is a matter of federal, not local law, 228 thus disposing of the matter for all jurisdictions. Of course, once judgment is obtained the cause of action merges into the judgment ${ }^{220}$ and interest runs on the judgment wherever the law so provides. The Federal Judicial Code contains such a specific provision ${ }^{230}$ and the courts have applied it to FLSA judgments. ${ }^{231}$

\section{E. Attorneys' Fees}

The Act provides that in addition to liquidated damages and costs, the plaintiff shall be allowed by the court "a reasonable attorney's fee to be paid by the defendant." ${ }^{232}$ Since this provision is of more than passing concern to the attorneys representing successful plaintiffs it is not surprising that a great number of cases have involved the question of what constitutes adequate remuneration to the attorney.

A study of the cases involving fees indicates that the primary factor influencing the size of the fee is the attitude of the court toward the FLSA generally and the rule of law governing the case in particular.' For example, in one case, ${ }^{233}$ the attorney had recovered, on behalf of his clients, the sum of $\$ 3,058.50$ and the court allowed the munificent fee of $\$ 250.00$. This is an extremely low fee compared to fees allowed in recoveries of similar amounts. ${ }^{234}$ The clue to the reason for the low fee is found in the court's sarcastic references to and analysis of Kirschbaum $v$. Walling ${ }^{235}$-the governing decision. ${ }^{236}$

In fixing the fee, the court's attitude toward the plaintiff is a factor that often equals, in importance, its attitude toward the law. Thus,

228. Ibid. The dogma on this subject is that state courts are bound by the Supreme Court interpretations on substantive matters relating to the FLSA but in practice and procedure the state rules govern. Ille v. Travis Oil Corp., I64 P. (2d) 998 (I945). It is a rule easier to state than apply. See Goodrich, Conflict of Laws (2d ed. I938) c. 5 .

229. See Restatement, Judgments (1942) $\$ 45$ (a) and comment a.

230. 36 STAT. II67 (IgIT), 28 U. S. C., \$ 8 II (I940).

231. Harris v. Crossett Lumber Co., 62 F. Supp. 856 (W. D. Ark. 1943), aff'd, I49 F. (2d) II6 (C. C. A. 8th, I945); Keen v. Mid-Continent Petroleum Corp., 63 F. Supp. 120 (N. D. Iowa, 1945).

232. 52 STAT. 1069 (1938), 29 U. S. C., \$216 (b) (1940).

233. Richardson v. Delaware Housing Association, 7 C. C. H. Lab. Cas. $\llbracket 61,583$ (S. D. Fla. I943).

234. For example, see the following: Wilson v. Shuman, 140 F. (2d) 644 (C. C. A. 8th, I944) (recovery $\$ 3,957.66$; fees allowed $\$ 494.7 \mathrm{I}$ ); Cahn v. Butler Building Corp., 9 C. C. H. Lab. Cas. ๆ 62,466 (N. D. I11. 1944) (recovery $\$ 3,662.37$; fee allowed $\$ 1,000)$; Cohn v. Decca Distributing Corp., 50 F. Supp. 270 (E. D. Pa. I943) (recovery $\$ 3,004.60$; fee allowed $\$ 500$ ) ; Cassone v. William Edgar John \& Associates, Inc., I85 Misc. 573, 57 N. Y. S. (2d) I69 (Sup. Ct. I945) (recovery $\$ 2,800$; fee allowed $\$ 1,500)$.

235. 3I6 U. S. 5 I7 (1942).

236. Richardson v. Delaware Heusing Ass'n, Inc., 7 C. C. H. Lab. Cas. at $₫ 64,657$ : "Confused, but bound by the impelling precedent, I follow the holding in $W$ alling $v$. Kirschbaum, supra. Ita lex scripta." 
in a Tennessee case ${ }^{237}$ the plaintiff, a night watchman, sued and recovered $\$ 805.80$ and the trial court awarded a fee of $\$ 300.00-a$ reasonable fee in view of the amount recovered. ${ }^{238}$ However, the court of appeals, although affirming the recovery, found that the plaintiff had attempted to pad his overtime, and that he had a couch upon which to sleep, "and undoubtedly did sleep away many hours he was paid overtime." ${ }^{239}$ Consequently the court reduced the attorney's fee from $\$ 300.00$ to $\$ 1.00$ and graciously gave the attorney a "lien upon the recovery for his services in the lower court and in this court." 240 The degree of defendant's fault has been regarded as relevant by some courts who have considered, in fixing fees, such matters as the absence of a wilful violation by the defendant ${ }^{241}$ and the defendant's good faith. ${ }^{242}$

It is submitted that all these considerations are immaterial and that the fee awarded should be calculated as though the controversy were an action by the attorney against his client on a quantum meruit count. A contrary rule will defeat the basic purpose of the Act and some courts have expressly so stated. ${ }^{243}$ Other courts, without discussing this aspect of the problem, have apparently reached the same conclusion since they consider factor's that would normally be considered in a quasi-contract action. These factors include the attorney's reputation and standing, ${ }^{244}$ the time and energy devoted to the case, ${ }^{245}$ the manner of presentation, ${ }^{246}$ the bar association's minimum fee schedule, ${ }^{247}$ and the amount recovered. ${ }^{248}$

237. Robinson \& Co. v. Larue, 25 Tenn. App. 284, 156 S. W. (2d) 359 (194I), aff'd, I78 Tenn. $197,156 \mathrm{~S}$. W. (2d) 432 (I94I).

238. For example, see the following: Porter, Adm'x v. Georgia Power \& Light Co,. 50 F. Supp. 959 (M. D. Ga. I943) (recovery $\$ 69 \mathrm{I} .54$; fee $\$ 400$ ) ; Johnston v. Firemen's Insurance Co., II C. C. H. Lab. Cas. II63,120, II5 N. Y. L. J. I614 (Sup. Ct. I946) (recovery $\$ 872.80$; fee $\$ 375$ ); of Gosinski v. Eclipse Glass Co., Inc., I3 Conn. Sup. 285 (Conn. C. P. Ct. I945) (recovery \$74I.34; fee \$150).

239. Robinson \& Co. v. Larue, 25 Tenn. App. 284, I56 S. W. (2d) 359, 362 (194I). 240. Ibid.

24I. South v. Lawley \& Son, Inc., 7 C. C. H. Lab. Cas. $\pi 61,682$ (D. Mass. I943), I 40 F. (2d) 439 (C. C. A. Ist, 1944), cert. denied, 322 U. S. 746 (1944).

242. Fiedler v. Potter, 180 Tenn. 176, 172 S. W. (2d) 1007 (1943).

243. Greenberg v. Arsenal Bldg. Corp., I44 F. (2d) 292 (C. C. A. 2d, r944), rev'd on other grounds, 324 U. S. 697 (1945); Hutchinson v. Barry, 50 F. Supp. 292 (D. Mass. 1943).

244. Cassone v. William Edgar John \& Associates, Inc., 185 Misc. 573, 57 N. Y. S. (2d) I69 (Sup. Ct. I945).

245. Dumas \& Dumas v. King, II C. C. H. Lab. Cas. $\pi 63,378$ (C. C. A. 8th, 1946) ; Ferguson v. Prophet Co., II C. C. H. Lab. Cas. II 63,297 (S. D. Ind. 1946); Corey v. Detroit Steel Corp., 52 F. Supp. I38 (E. D. Mich. 1943); Phelan v. Carstens, Linnekin \& Wilson, I87 Misc. 352, 62 N. Y. S. (2d) 214 (N.'Y. Mun. Ct. I946); $c f$. Poe v. Phelps Dodge Corp., 9 C. C. H. Lab. Cas. I 62,656 (D. Ariz. 1944).

246. E. H. Clarke Lumber Co. v. Kurth, I52 F. (2d) 94I (C. C. A. 9th, I945);

Redfern v. Jax Beer Co., 4 C. C. H. Lab. Cas. I 60,402 (N. D. Tex. I94I), revd on other grounds, I24 F. (2d) I72 (C. C. A. 5 th, I94I).

247. Corey v. Detroit Steel Corp., 52 F. Supp. I38 (E. D. Mich. I943).

248. Shetter v. Somerville Iron Works, 8 C. C. H. Lab. Cas. $\pi 62, I 66$ (E. D. Tenn. 1944). 
The last factor listed is, of course, of great importance. ${ }^{249}$ A statistical survey of all cases found by the writers demonstrates that the average fee in FLSA cases is approximately $20 \% .^{250}$ This is especially accurate in cases involving recoveries of large sums. ${ }^{251}$ However, if the work of the attorney merits it, especially in cases involving recoveries of smaller sums, the fee may even exceed the amount recovered. ${ }^{252}$

Certain words of caution may be of assistance to counsel representing claimants in FLSA suits :

I. Only one fee is permitted although there may be a large number of plaintiffs. ${ }^{253}$ However, the fact that the attorney found it necessary to employ an assistant attorney may be considered in fixing the fee. ${ }^{254}$

2. In selecting a forum the counsel fee should be considered as part of the plaintiff's claim for recovery so as to eliminate courts of limited monetary jurisdiction. For example, where an action was brought in a court whose jurisdiction was limited to $\$ 3,000.00$ and $\$ 3,000.00$ was recovered the court felt that it could not add a counsel fee. ${ }^{255}$ For similar reasons an FLSA claim in bankruptcy should include an allowance of counsel fees as part of the wage claim. If a separate application is made for the fee, it will be denied. ${ }^{256}$

3. The court may permit the jury to fix the fee, ${ }^{257}$ but most frequently the court fixes the fee itself. The argument that this deprives the defendant of his right to trial by jury has been rejected in ac-

249. See, e. g., Roberg v. Phipps Estate, Ir C. C. H. Lab. Cas. $\pi 63,263$ (C. C. A. 2d, 1946), where the circuit court of appeals, in addition to awarding a counsel fee for arguing the appeal stated that since the appellate decision had increased the amount recovered the trial court might review its award of a counsel fee to increase it.

250. The arithmetic average is $18.3 \%$; the weighted average is $19.7 \%$.

251. Poe v. Phelps Dodge Corp., 9 C. C. H. Lab. Cas. I 62,656 (D. Ariz. 1944) (recovery \$57,071.30; fee \$10,000); Steiner v. Pleasantville Constructors, Inc., 9 C. C. H. Lab. Cas. I 62,397, II2 N. Y. L. J. I I80 (Sup. Ct. I944) (recovery $\$ 15,745.50$; fee $\$ 3,000)$; Williams v. Wisconsin Electric Power Co., 8 C. C. H. Lab. Cas. T62,033 (C. C. Milwaukee Co., Wis., I943) (recovery $\$ 48,000$; fee $\$ 9,600$ ).

252. Burke v. Le Crone-Benedict Ways, Inc., 63 F. Supp. 883 (E. D. Mich. 1945) (recovery \$210.76; fee \$150); Morgan v. Atlantic Coast Line R. Co., 32 F. Supp. 6I7 (S. D. Ga. 1940) (recovery \$156.80; fee \$250); Wilson Oil Co. v. Hardy, 49 N. Mex. 337,164 P. (2d) 209 (1945).

253. Distelhorst v. Day \& Zimmerman, 58 F. Supp. 334 (S. D. Iowa, I944), appeal dismissed per curiam, I50 F. (2d) 54I (C. C. A. 8th, I945); cf. DeLuca v. West 26th St. Corp., II C. C. H. Lab. Cas. II 63,322, I I6 N. Y. L. J. IIS (N. Y. City Ct. 1946).

254. Timberlake v. Day \& Zimmerman, Inc., 7 C. C. H. Lab. Cas. 161,623 (S. D. Iowa, 1943).

255. Caperna v. Williams-Bauer Corp., I85 Misc. 687,57 N. Y. S. (2d) 254 (N. Y. City Ct. I945), aff'd no opinion, I86 Misc. 27, 58 N. Y. S. (2d) 876 (Sup. Ct. I945). Thus, in Schneider \& Son, Inc. v. Justice, $293 \mathrm{Ky}$. 126, I68.S. W. (2d) $59 \mathrm{I}$ (Ky. App. I943) it was held that attorney's fees may be included for the purpose of determining the jurisdiction of a court with a lower limit to monetary jurisdiction.

256. In re L. E. Elliott Brokerage Co., 48 F. Supp. I44 (D. Kan. I942).

257. Acme Lumber Co. v. Shaw, 243 Ala. 421, Io S. (2d) 285 (I942); Ashenford v.

L. Yukon \& Sons Produce Co., 237 Mo. App. 124r, 172 S. W. (2d) 881 (1943). 
cordance with the usual rule that the inviolability of jury trial is confined to common law causes of action. ${ }^{258}$

4. The attorney should be careful to see that evidence relating to the question of the fee is before the court. ${ }^{259}$ This has been done by direct testimony of the attorney, ${ }^{260}$ the submission of briefs, ${ }^{261}$ and special hearings set for the sole purpose of considering the fee. ${ }^{262}$

5. For successfully defending the decision of the lower court, the attorney is entitled to a separate and distinct fee. ${ }^{263}$ The better procedure seems to be to apply directly to the appellate court for the fee for defending a judgment on appeal. ${ }^{204}$ However, where a federal district court refused to grant a fee for appellate work, the circuit court of appeals reversed and remanded, stating that the responsibility for fixing fees properly is that of the trial court where the work begins and ends and where the value of the services rendered can best be estimated. ${ }^{265}$ Fees for arguing appeals are never large. An examination of numerous cases reveals that the average allowance has been approximately $\$ 325.00$, the largest fee allowed being $\$ 700.00^{200}$ and the smallest $\$ 50.00 .{ }^{287}$

6. On the question of fees the trial court's decision is subject to review but the likelihood of obtaining a reversal, except in cases of egregious error, is remote in view of the rule that the trial court may exercise its discretion in fixing the fee. ${ }^{288}$ However, where the

258. Cudahy Packing Co. v. Bazanos, 245 Ala. 73, I5 S. (2d) 720 (r943); Edwards v. South Side Auto Parts Co., I80 S. W. (2d) Ior 5 (Mo. App. 1944).

259. Strand v. Garden Valley Telephone Co., 51 F. Supp. 898 (D. Minn. 1943); Ashenford v. L. Yukon \& Sons Produce Co., 237 Mo. App. 124I, 172 S. W. (2d) 88I (1943) ; cf. Agnew v. Johnson, 352 Mo. 222, 176 S. W. (2d) 489 (1943).

260. Ashenford v. L. Yukon \& Sons Produce Co., 237 Mo. App. I24r, 172 S. W. (2d) 88I (1943). See also Ferguson v. Prophet Co., II C. C. H. Lab. Cas. I 63,297 (S. D. Ind. 1946).

26r. Deutsch v. Heywood-Wakefield Co., 7 C. C. H. Lab. Cas. I6r,596 (S. D. N. Y. 1943).

262. Bell v. Porter, II C. C. H. Lab. Cas. I63,I47 (N. D. IIl. I946); Smith v. Ogle, 164 P. (2d) 992 (Okla. 1945).

263. DePasquale v. Williams-Bauer Corp., I5I F. (2d) 578 (C. C. A. 2d, I945), cert. denied, 66 Sup. Ct. 1007 (1946); Republic Pictures Corp. v. Kappler, I5I F. (2d) 543 (C. C.A. 8th, 1945, aff'd, 327 U. S. 757 (I946); Ispass v. Pyramid Motor Freight Corp., I52 F. (2d) 619 (C. C. A. 2d, I945).

264. See, e. g., Dumas \& Dumas v. King, II C. C. H. Lab. Cas. I 63,378 (C. C. A. 8th, I946); Maddrix v. Dize, 6I F. Supp. 946 (D. Md. r945), rev'd, I53 F. (2d) 274 (C. C. A. 4th, 1946); E. H. Clarke Lumber Co. v. Kurth, I5z F. (2d) 94I (C. C. A. 9th, 1945) ; cf. Mid-Continent Petroleum Corp. v. Keen, II C. C. H. Lab. Cas. $\pi 63,353$ (C. C. A. 8th, I946).

265. Maddrix v. Dize, I53 F. (2d) 274 (C. C. A. $4^{\text {th, I946). }}$

266. Maddrix v. Dize, r55 F. (2d) rorg (C. C. A. 4th, 1946).

267. Anderson v. N. Y. Sav. Bank, I82 Misc. 945, 5I N. Y. S. 425 (Sup. Ct. I944). 268. For cases in which plaintiff appealed unsuccessfully see Schroeder Co., Inc. v. Clifton, I53 F. (2d) 385 (C. C. A. Ioth, I946), cert. denied, 66 Sup. Ct. I35I (1946); Sullivan \& Cromwell v. Colorado Fuel \& Iron Co., 96 F. (2d) 2rg (C. C. A. Ioth, I938); Robinson \& Co. v. Larue, I78 Tenn. I97, I56 S. W. (2d) 432 (I94I). For an unsuccessful appeal by defendant see Fiedler v. Potter, 7 C. C. H. Lab. Cas. f] 61,747 (Tenn. I943). 
trial court errs and an appellate court can be convinced that there was error a fee can be increased ${ }^{269}$ or lowered ${ }^{270}$ on appeal.

7. It has been held that although the employees settle the case out of court the attorney is still entitled to his statutory fee. ${ }^{271}$ The court states: ". . . clients cannot settle the lawyer out of his reasonable attorney fees." 272

8. Although it has become general practice for attorneys to insure themselves against low court-awarded fees by separate fee contracts with the plaintiffs, judicial treatment of such contracts has rarely arisen. One court, in considering this question, stated that the practice is contrary to the policy of the Act since it imposes a burden that the law sought to remove. ${ }^{273}$ However, the same court admitted that the practice is not prohibited by the Act. ${ }^{274}$

Two courts have indicated in dicta that if there is a fee agreement the court should not award an attorney's fee exceeding the amount agreed upon by the plaintiff and his attorney. ${ }^{275}$ However, it has been held that if the court intends to award an attorney's fee lower than that specified in the fee agreement the figure in the fee agreement should not be considered. ${ }^{276}$

269. Maddrix v. Dize, I55 F. (2d) Iorg (C. C. A. 4th, I946) ; Greenberg v. Arsenal Bldg. Corp., I44 F. (2d) 292 (C. C. A. 2 d, I944), revd on other grounds, 324 U. S. 697 (1945) ; Easley v. Edgard Realty Corp., 270 App. Div. 184, 59 N. Y. S. (2d) 24I (Ist Dep't. 1945), aff'd, 296 N. Y. 579 (1946).

270. Poe v. Phelps Dodge Corp., 9 C. C. H. Lab. Cas. $\mid 62,656$ (D. Ariz. I944). 27. McLendon v. Bewley Mills, 3 C. C. H. Lab. Cas. If 60,247 (N. D. Tex. 1940). 272. Ibid.

273. Skidmore v. Casale, II C. C. H. Lab. Cas. I63,370 (S. D. N. Y. 1946). 274. Ibid.

275. Skidmore v. Casale, II C. C. H. Lab. Cas. I63.370 (S. D. N. Y. I946); Aucoin v. Mystic Waste Co., 55 F. Supp. 672 (D. Mass. I944).

276. Skidmore v. Casale, II C. C. H. Lab. Cas. I 63,370 (S. D. N. Y. 1946). 